\title{
The Fur Formation, a late Paleocene ash-bearing diatomite from northern Denmark
}

\author{
GUNVER KRARUP PEDERSEN and FINN SURLYK
}

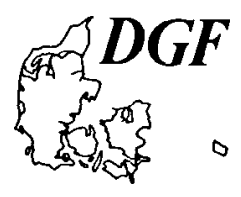

Pedersen, G. K. and Surlyk, F.: The Fur Formation, a late Paleocene ash-bearing diatomite from northern Denmark. Bull. geol. Soc. Denmark, vol 32, pp. 43-65, Copenhagen, November, 15th, 1983. https://doi.org/10.37570/bgsd-1983-32-03

The Fur Formation (new) is here erected as a formal lithostratigraphical unit. It is a marine diatomite with numerous layers of volcanic ash, and has previously been referred to as "Moler" or the "Mo-clay Forma-tion". The formation is of late Paleocene age and the Paleocene-Eocene boundary is located within a hiatus between the Fur Formation and the overlying Knudshoved Member of the Røsnæs Clay. The Fur Formation is subdivided into a lower Knudeklint Member and an upper Silstrup Member. The sedimen-tary facies, ichnocoenoses and areal distribution of the formation are described as the basis for an interpretation of the depositional environment.

G. K. Pedersen, Geologisk Centralinstitut, Øster Voldgade 10,DK-1350 Copenhagen K, Denmark; F Surlyk, Grønlands geologiske Undersøgelse, Øster Voldgade 10, DK-1350 Copenhagen K, Denmark, February 18th, 1983.

The impressive coastal cliff exposures of the Fur Formation, where black layers of volcanic ash are interbedded with pale weathering clayey diatomite, has attracted the attention of numerous geologists through the last hundred years. The occurrence of well-preserved vertebrate and insect fossils, and the relatively fresh nature of the volcanic ash has resulted in a relatively rich literature within the fields of palaeontology, igneous petrology and stratigraphy.

The approach of the present study has been sedimentological and lithostratigraphical, with the emphasis on features such as sedimentary structures and trace fossils, which can be easily studied throughout the formation without the element of luck required for the collection of macrofossils. The numerous isochronous and identifiable ash layers provide a unique means of precise vertical and lateral correlation of the sedimentary facies. The spatial and temporal facies distribution is thus relatively well known and provides a sound basis for the interpretation of the sedimentary environment.

\section{Lithostratigraphy}

\section{Fur Formation; (New Formation) History}

The interbedded diatomites and ash layers described here as the Fur Formation have a long history in the Danish geological literature. While the diatomites in themselves have received relatively little attention the fossil content and the interbedded ash layers have been intensively studied. The formation is exposed in glacially folded and thrust faulted masses brought into their present position during the Quaternary (Gry, 1940, 1964, 1979). The sediments were mentioned for the first time as early as in 1763 by Pontoppidan. A more detailed description was given by Forchhammer (1835) who interpreted the dominantly black volcanic ash layers as coaly sandstones. He named the sequence "Moeformationen" and suggested a limnic origin because of the abundance of insect fossils. The diatoms were, however, identified as marine by Heiberg (1863), and further studied by Prinz \& Ermengem (1883), Prinz (1885) and Stolley (1899). The presence of volcanic ash was first recognized by Prinz \& Ermengem (1883) and the mineralogical composition and the graded bedd- 


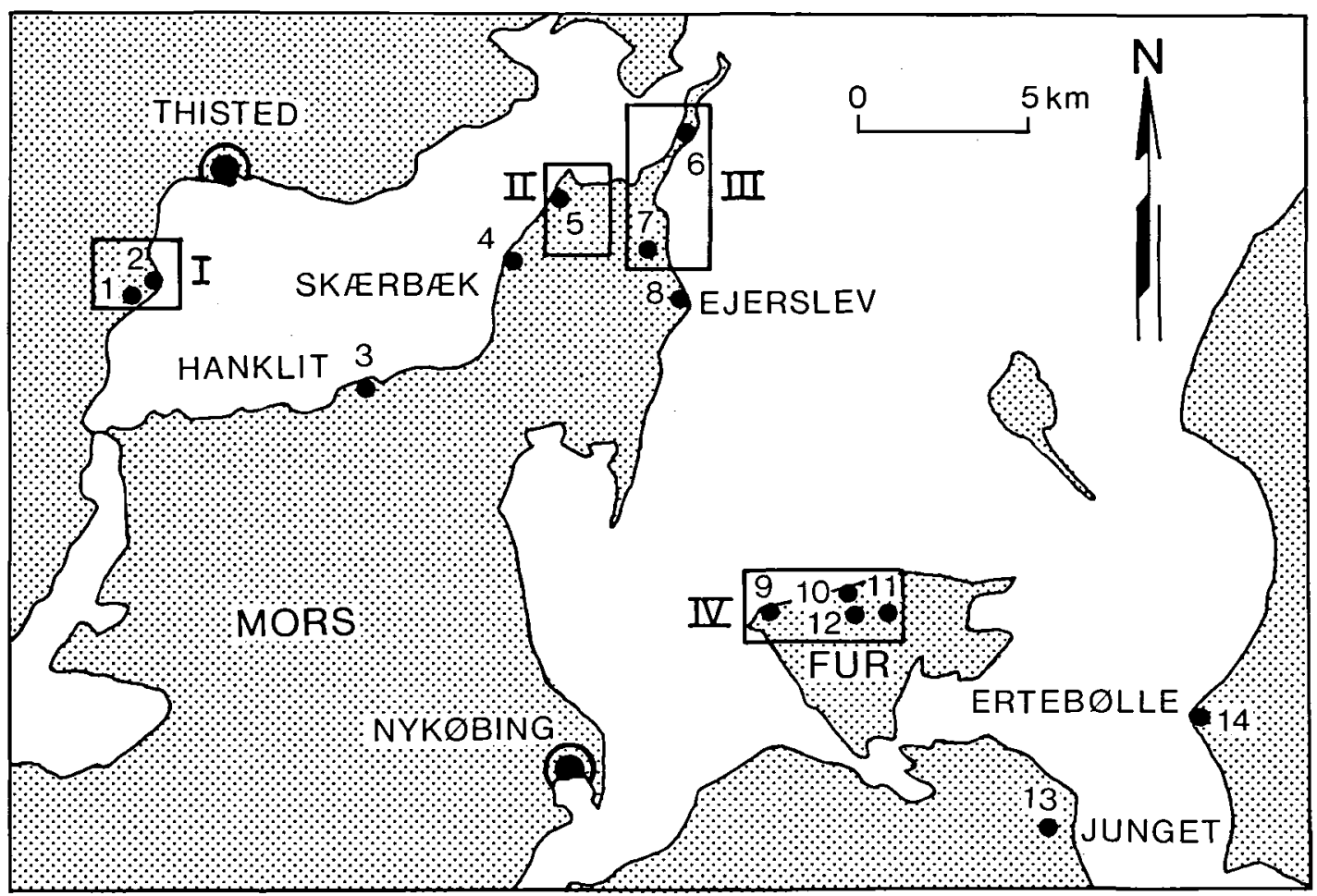

Fig. 1. Location map showing the studied area in northern Jutland. Inset maps I-IV shown on fig. 2 . The location of type locality and reference localities is shown on these maps. The localities at which sedimentological logs have been measured (fig. 4) are indicated by black dots and the numbers $1-14$.

ing of the ash layers was described by Prinz (1885) and Bøggild (1903, 1918).

The age relations of the formation were discussed on the basis of a few fossil finds by Ravn (1897, 1906, 1907), Ussing (1904), and Bøggild (1903). Grönwall (1908) and Hartz (1909) established the formation as being of Early Eocene age in accordance with a proposal by Stolley (1899), but the discussion of the age was recurrently revived (Harder, 1922; Rosenkrantz, 1924; Gry, 1935; Andersen, 1944).

An early environmental interpretation was given by Using (1904 p. 148): "From these different organic remains one can conclude, that the Mo-clay must have been deposited not long from a coast and in quiet water, perhaps in a luke-warm marine bay" (translated from Danish by the authors). A contrasting environment was envisaged Andersen (1944) who suggested a water depth of about $2000 \mathrm{~m}$ possibly with stagnant bottom conditions.

Dinesen, Michelsen \& Lieberkind (1977 p. 7) included all the ash-bearing clay deposits of northern Denmark in an informal unit termed "Clay with Volcanic Ash" which locally in the Limfjord area was developed as "Mo Clay with Volcanic Ash".

More recently the diatoms have been described by Benda (1972), the silicoflagellates by Martini (1974, 1977) and Perch-Nielsen (1976), and the dinoflagellates by Hansen (1979) and Heilmann-Clausen (1982). Macrofossils have been described by Nielsen $(1959,1960,1963)$, Bonde (1966) and Hoch (1975), while the insect fauna was studied by Larsson (1975). The mineralogy of the ash layers have been studied by Pedersen, Engell \& Rønsbo (1975), Rønsbo, Pedersen \& Engell (1977), and Pedersen \& Jørgensen (1981).

The most recent environmental interpretations are given by Bonde $(1974,1979)$, Surlyk (1980), and Pedersen (1978, 1981). 

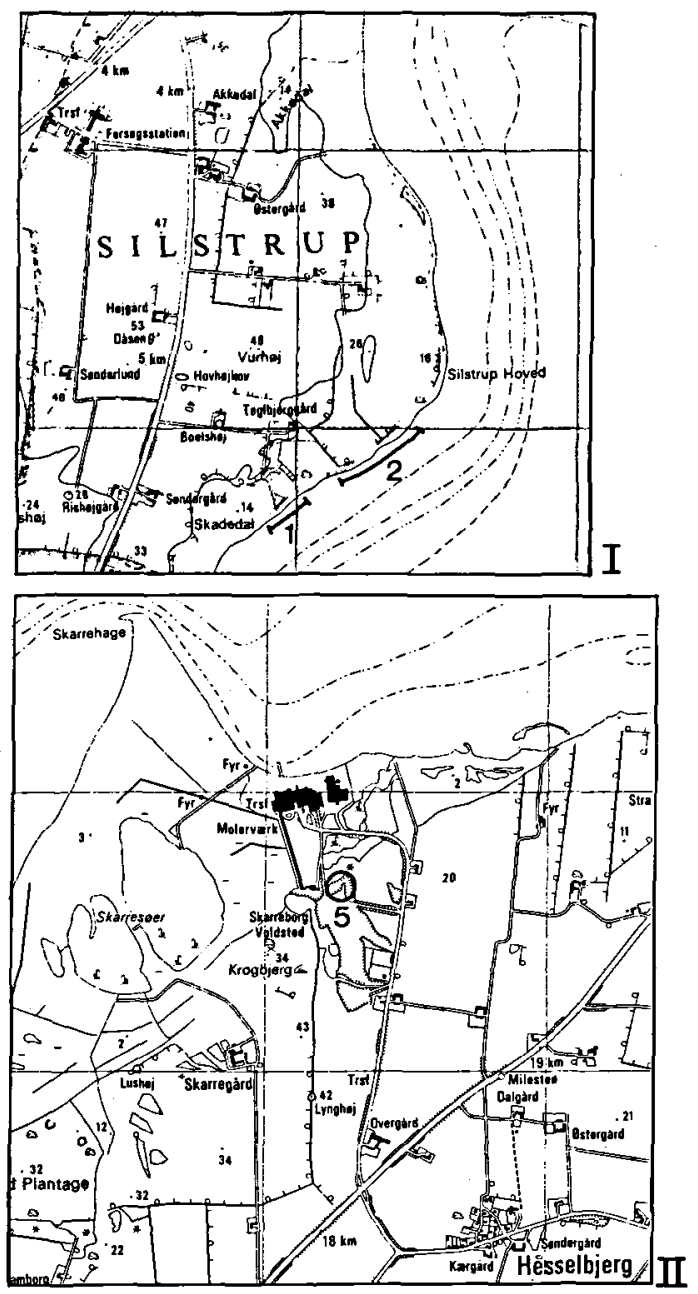

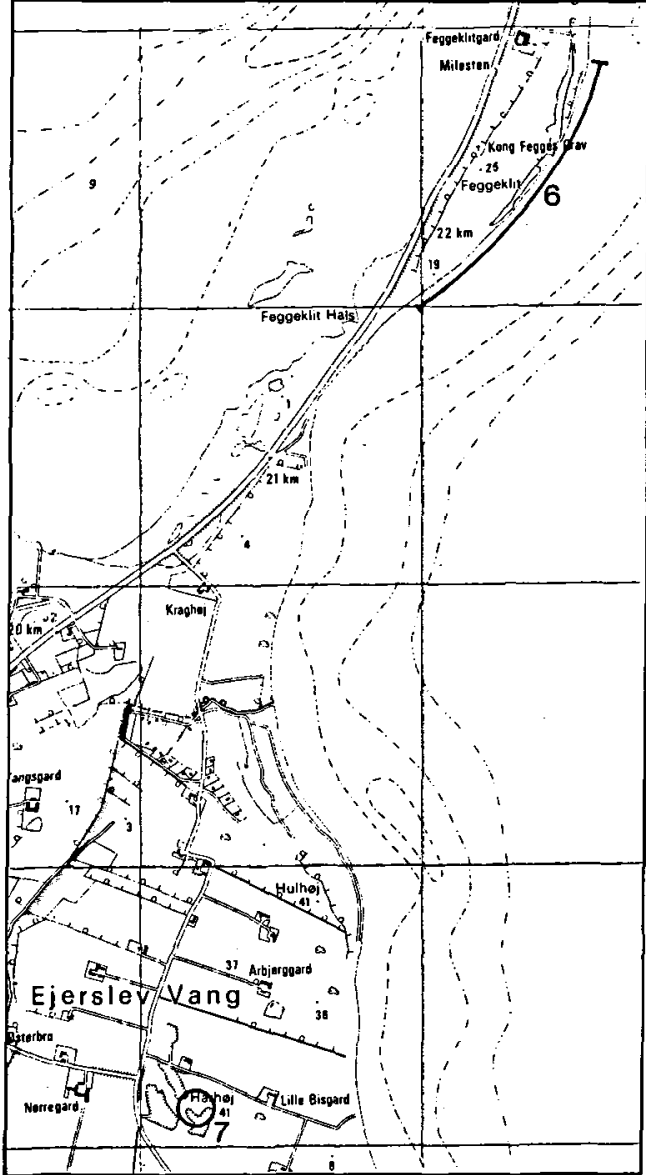

III

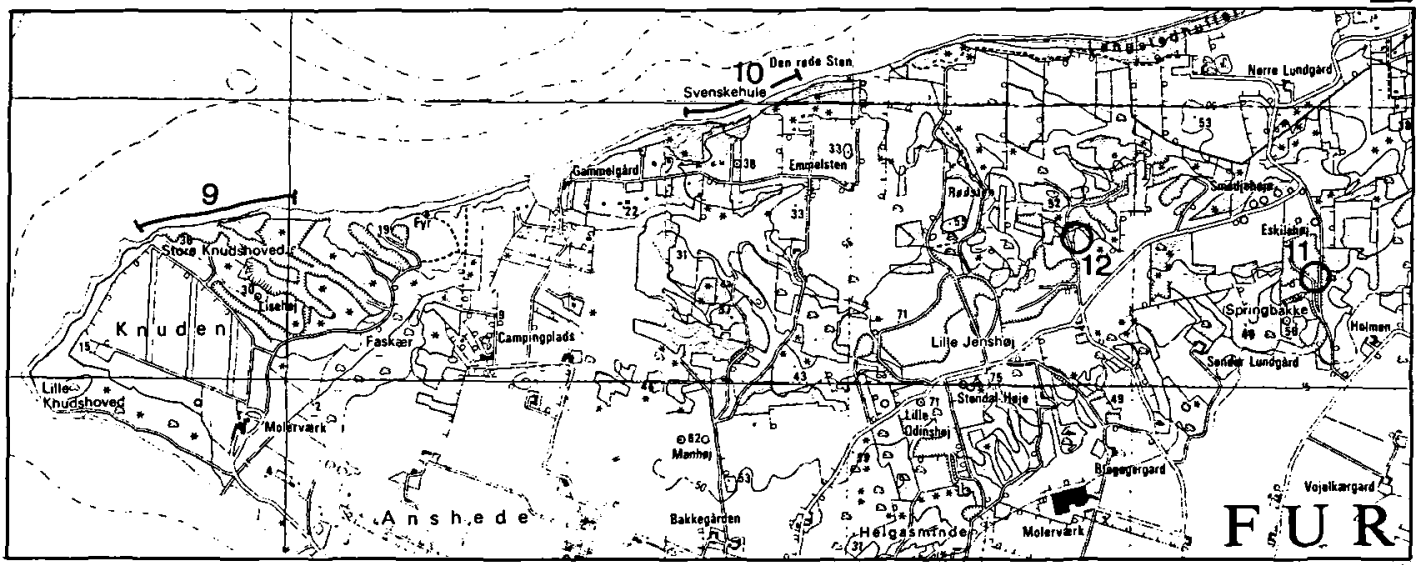

Fig. 2. Maps showing the position of type- and reference localities. Published with permission (A83) of the Geodetic Institute from the map sheets 1116 I NV Thisted, 1116 I NØ Alsted and 1216 IV SV Livø. Distance between the grid lines is $1 \mathrm{~km}$.

Map I: locality 1: South cliff at Silstrup, partial type locality of the Fur Formation, and of the Silstrup Member. Locality 2:

"Firkanten" at Silstrup, reference section of the Fur Formation.

Map II: locality 5: Pit of Skarrehage Molerværk with reference section of the Fur Formation.

Map III: localities 6: Feggeklit, and 7: Harhøj, both showing reference sections of the Fur Formation.

Map IV: locality 9: Fur Knudeklint, partial type locality of the Fur Formation and of the Knudeklint Member of the Fur Formation.

Localities 10: Stolleklint, 11: Eskildshøj and 12: Ll. Jenshøj are all reference localities of the Fur Formation. 
Name

The formation is named after the island of Fur where the type section is located (fig. 2). In the Danish literature the formation has informally been referred to as the Moler (Eng. Mo-clay), spelled in a variety of ways. According to Rørdam (1909 p. 89) the prefix "Mo" is very old and has been applied to various whitish, fine-grained sediments. It also appears in the Swedish grain-size scale of Atterberg (1903), where it describes the coarse silt to fine sand grade.

The name Fur Formation was first proposed by Pedersen (1978) in an unpublished thesis. Bonde (1979) and Surlyk (1980) used the name with reference to Pedersen's work, while Friis, Nielsen and Heilmann-Clausen (1981) and Buchardt (1981) adopted the term, which was still not formally defined. It is therefore considered appropriate to emphasize that the formation and its members are formally erected in the present paper.

\section{Type section}

The coastal cliff Knudeklint on the island of Fur (figs 2,3 ), where the longest section through the formation is exposed.

\section{Reference sections}

Silstrup south cliff (figs 2,3) where the upper boundary is exposed; Skarrehage (figs 2, 4), Feggeklit (figs 2, 4), Harhøj (figs 2, 4), Stolleklint (figs 2, 4).

\section{Thickness}

The thickness of the formation is about $60 \mathrm{~m}$ (Bøggild 1918). A composite section from Silstrup south cliff and Fur Knudeklint with supplementary measurements at Stolleklint through the whole formation measures $61 \mathrm{~m}$ (fig. 3).
Lithology

The formation is here defined as essentially a clayey diatomite with a large number of volcanic ash layers. The latter are widely distributed in contemporaneous sediments in the northern part of Denmark (Andersen, 1937; Friis et al., 1981), and while they form a characteristic constituent, they are not considered diagnostic for the formation.

The diatomite - The diatomite is a dark-grey sediment which weathers in whitish-yellowish colours. It is highly porous and has an average density of $0.8 \mathrm{~g} / \mathrm{cm}^{3}$. It consists of marine diatoms, c. $0.02-0.2 \mathrm{~mm}$ in size and of clay minerals, mainly montmorillionite (Pedersen, 1978).

The dominant sedimentary structure is a fine parallel lamination which can be more or less obliterated by bioturbation (fig. 5). Levels of laminated diatomite may be followed throughout the formation (Pedersen, 1981). Sedimentary structures produced by current or wave activity seem to be virtually absent, although subtle low-angle unconformities in the lamination may be observed possibly reflecting the occasional presence of very weak bottom currents. Rare small-scale slump structures also occur.

The lamination is seen as alternating white, whitish and brownish mm-thick laminae composed of diatom frustules and clay. The relative density of diatoms varies from lamina to lamina, in no recognizable pattern (Pedersen, 1981 fig. 4). In the diatomite bioturbation occurs as diffuse mottling, and well defined trace fossils can only be recognized at the boundary between diatomite and volcanic ash or more rarely in horizons of calcareous concretions (Pedersen, 1978). The trace fossil fauna which is described below includes Planolites, several forms of Teichichnus, Chondrites type C of Osgood (1970), and an ichnospecies of Taenidium.

Macrofossils are rare and include insects (Henriksen, 1922; Heie, 1970; Larsson, 1975; Willmann, 1977), vertebrates (fish and a few birds and turtles) (Nielsen, 1959, 1960, 1963; Bonde, 1966, 1979; Hoch, 1975), and plants (Hartz, 1909; Koch, 1960; Larsson, 1975) while invertebrates are extremely rare (Bonde, 1966; Rasmussen, 1972). The species of diatoms have been listed by Heiberg (1863), Stolley (1899), 

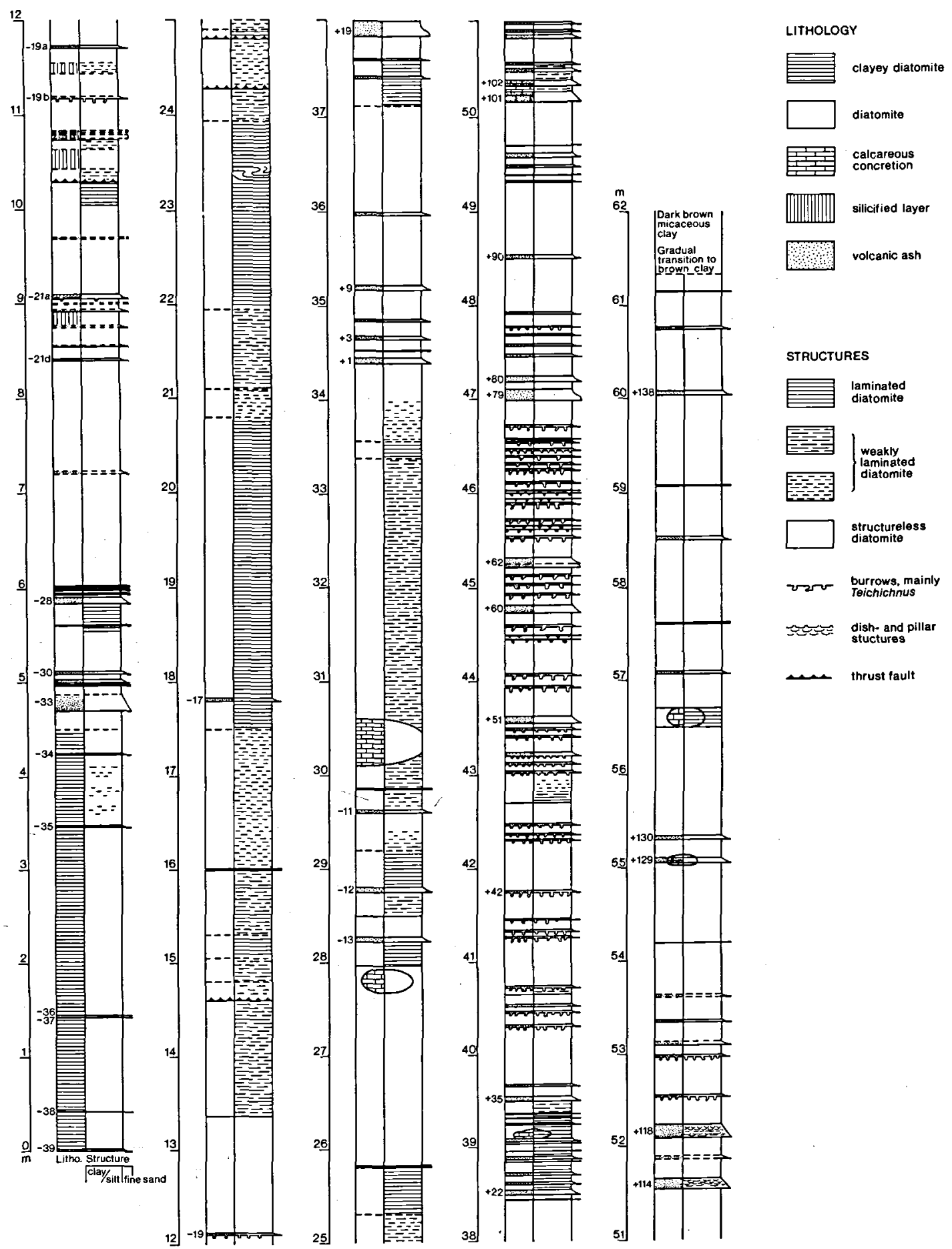

Fig. 3. Type section of the Fur Formation. The part from ash layer -34 to above +118 was measured at Fur Knudeklint (loc. 9 , map IV, fig. 2). From +118 to above ash layer +140 the section was measured at the south cliff at Silstrup (loc. 1, map I, fig. 2). 


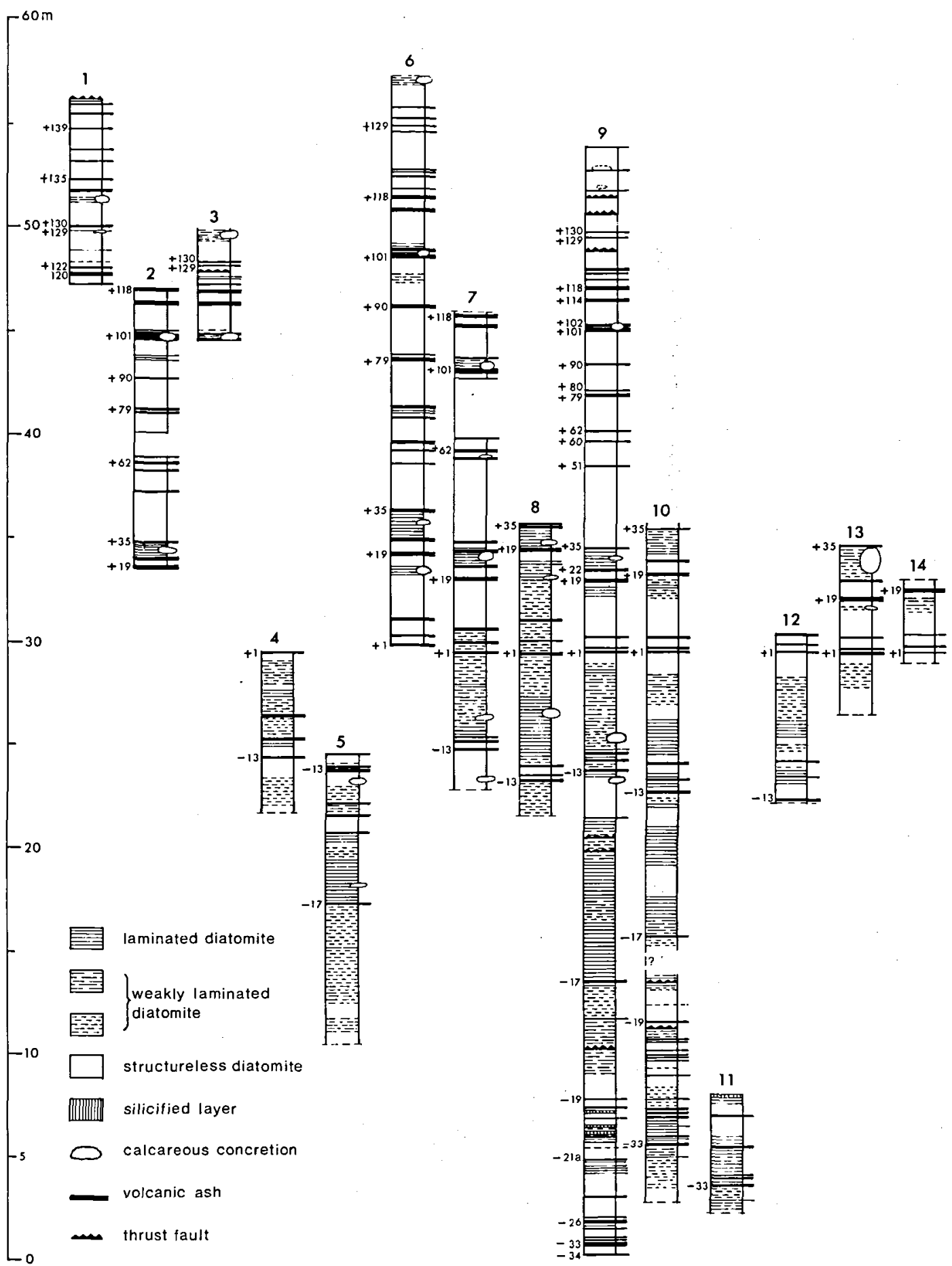

Fig. 4. Type and reference sections of the Fur Formation. The numbers above the sections refer to the localities shown in figs 1 and 2. 

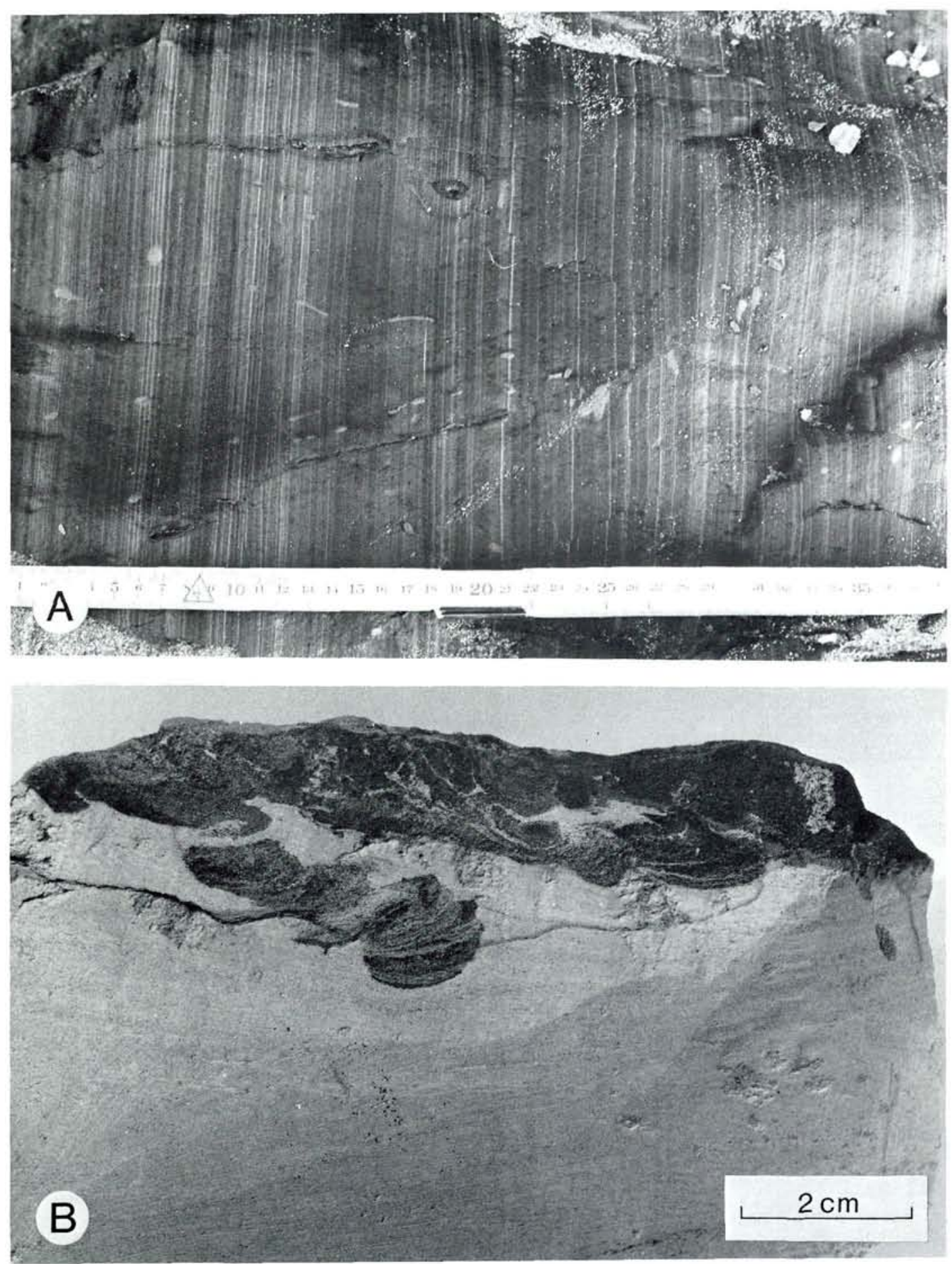

Fig. 5. a) Laminated diatomite. Ruler (in $\mathrm{cm}$ ) for scale. Top to the right. b) Structureless diatomite overlain by dark bioturbated ash layers. Ash filled burrows penetrate the top of the diatomite. 


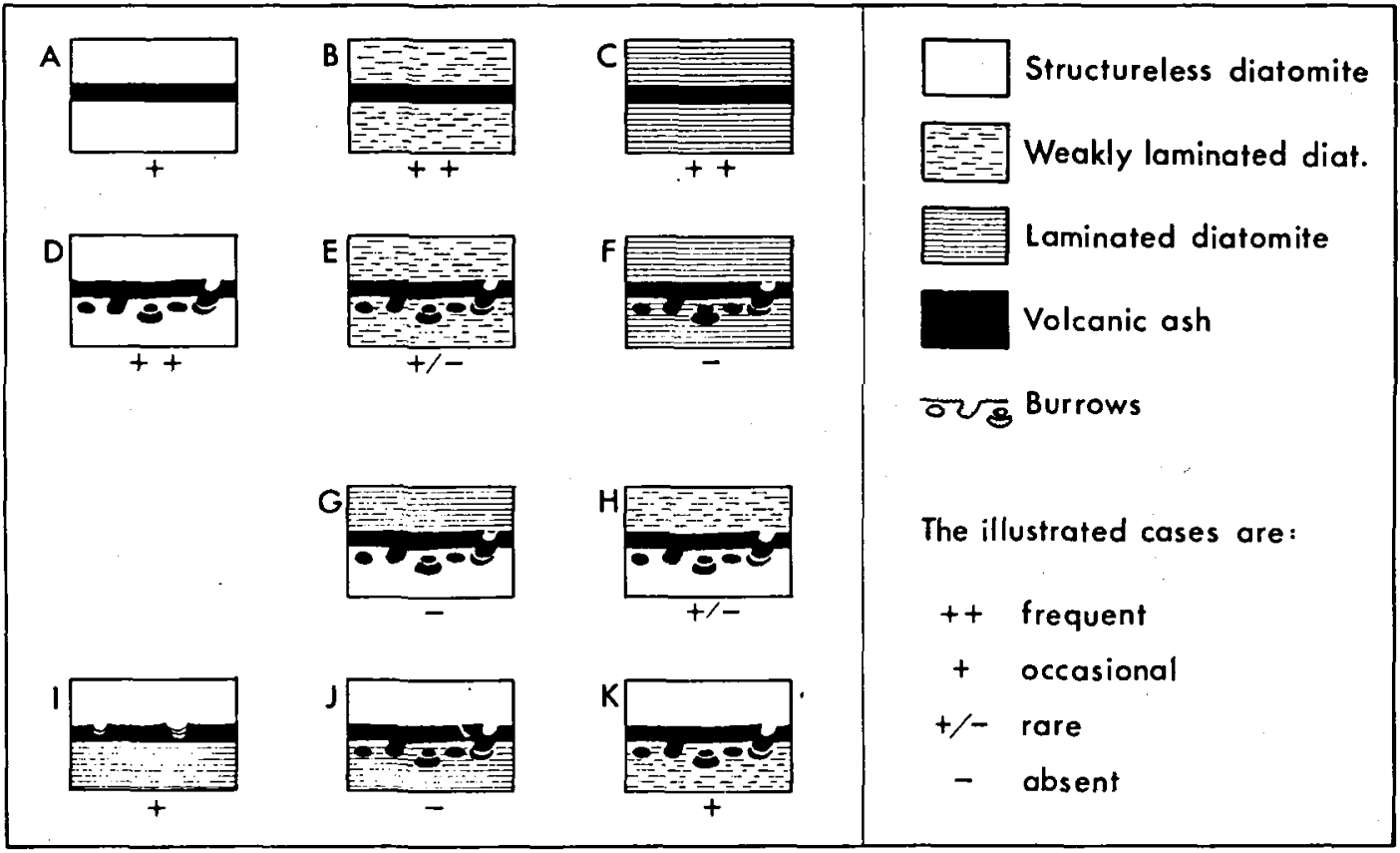

Fig. 6. Examples of observed and hypothetical relationships between ash layers and diatomite facies.

A-F illustrate ash layers within one diatomite facies, While G-K illustrate situations where ash layers separate two different facies. The frequencey with which the illustrated cases occur in the measured sections is indicated.

A illustrates that intensive bioturbation may be ascribed to organisms living close to the sediment surface (cf. D).

A, B and C show that all diatomite facies may be bounded above or below by ash layers, with no sign of bioturation, and such layers may also separate any two different facies. Therefore only facies transitions that might conceivably correspond to a bioturbated ash layer are illustrated in G-K. Non- or slightly bioturated diatomite rarely overlies bioturbated ash layers (G, $H$ ); this together with the evidence of $\mathrm{I}, \mathrm{J}$ and $\mathrm{K}$, indicates that ash layers were burrowed by benthos inhabiting the overlying diatomite.

That the presence or absence of burrowing benthos was determined not by grain size but by the content of dissolved oxygen is deduced from: (1) the fact that possibilities C, F and I are frequent, absent and occasionally occurring respectively, and (2) from the contrast between I, J, K and D.

Hartz (1909) and Benda (1972), the silicoflagellates have been described by Martini (1974, 1977) and Perch-Nielsen (1976), and the dinoflagellates have been studied by Hansen (1979) and Heilmann-Clausen (1982). CaIcareous microfossils are lacking in the Fur Formation.

Trace fossils - The trace fossils are generally seen as ash-filled burrows in diatomite beneath ash layers, but diatomite-filled burrows in the top of ash layers also occur. The animals producing the trace fossils mainly lived in the diatomaceous sea-bottom. The ash layers, by their colour and grain-size contrast, only serve to outline them. This may be concluded from the situations shown in fig. 6 , which demonstrate that the presence of the trace fossil producing organisms was governed by the diatomite facies rather than by the availability of the coarser-grained substrate formed by the ash layers. It should be emphasized that these organisms postdate those, which produced the structureless diatomite through complete bioturbation.

The diatomite is a fine-grained, and probably originally organic-rich, sediment which accumulated slowly, and the ichnocoenosis is dominated by the activity of deposit feeders. These are represented by Planolites, various forms of Teichichnus, Phycodes, Chondrites, type C (Osgood, 1970) and Taenidium ichnosp. (figs 7-12).

The variations within the ichnogenus Teichichnus are reflected by the shape and angle of the spreiten, as these may be more or less curved, parallel of fan-shaped, and may vary from perpendicular to very low angles to the bedding planes (fig. 7). The burrows of Teichichnus and Planolites are roughly of the 

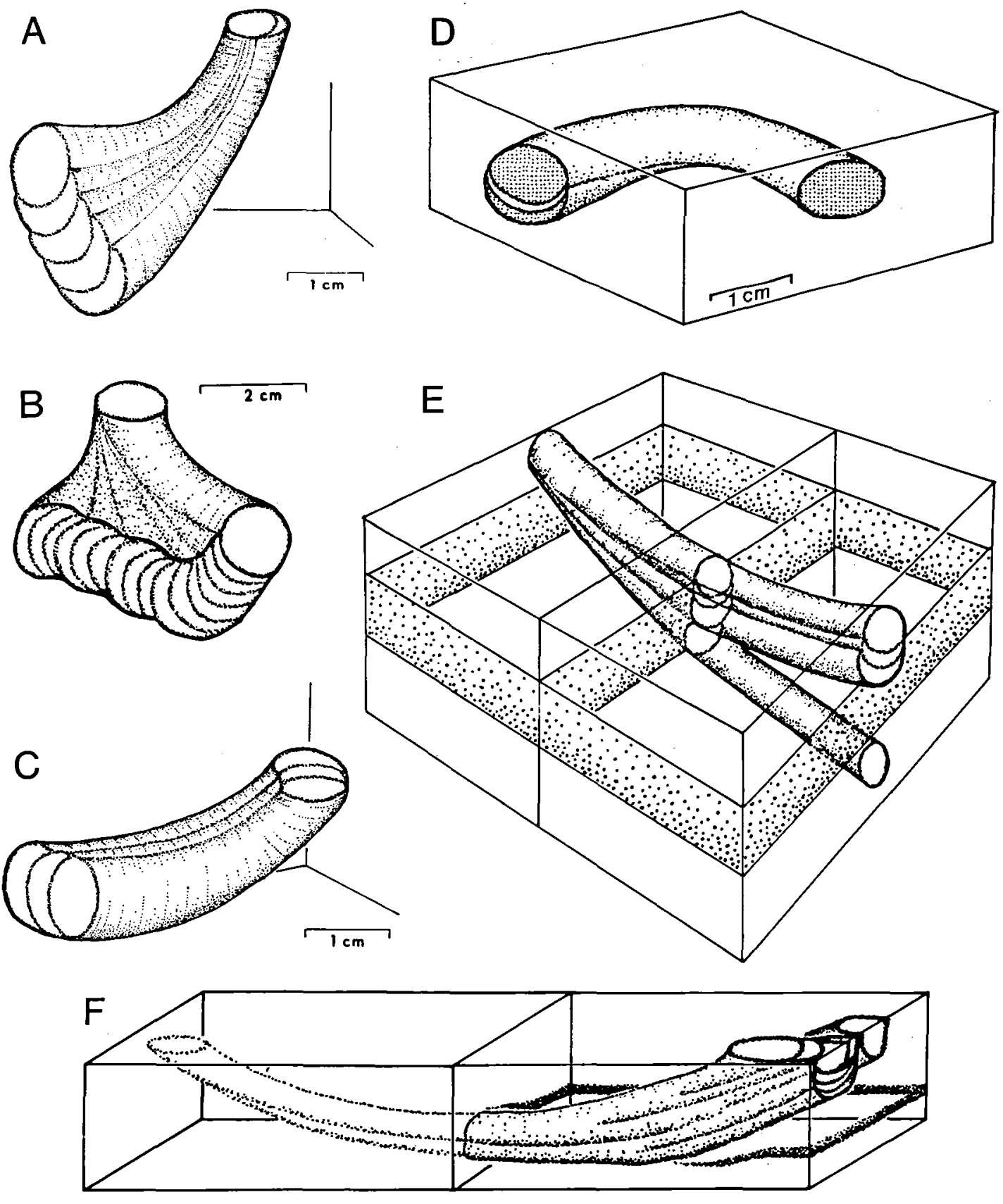

Fig. 7. A, B, C: Generalized sketches of trace fossils reffered to the ichnogenus Teichichnuis. A is the most abundant form. D: Trace fossil with an incipient spreite occupying an intermediate position between the ichnogenera Planolites and Teichichnus. E, F: Larger burrow systems strongly indicating that Planolites and Teichichnus were created by the same or by closely related species. Figure $\mathrm{F}$ is perhaps closer to Phycodes than to Teichichnus. The diameter of the burrows is $0.5-1.0 \mathrm{~cm}$.

$A, B, E$ and $F$ all illustrate the narrowing of the spreiten towards one end of the trace fossil. 


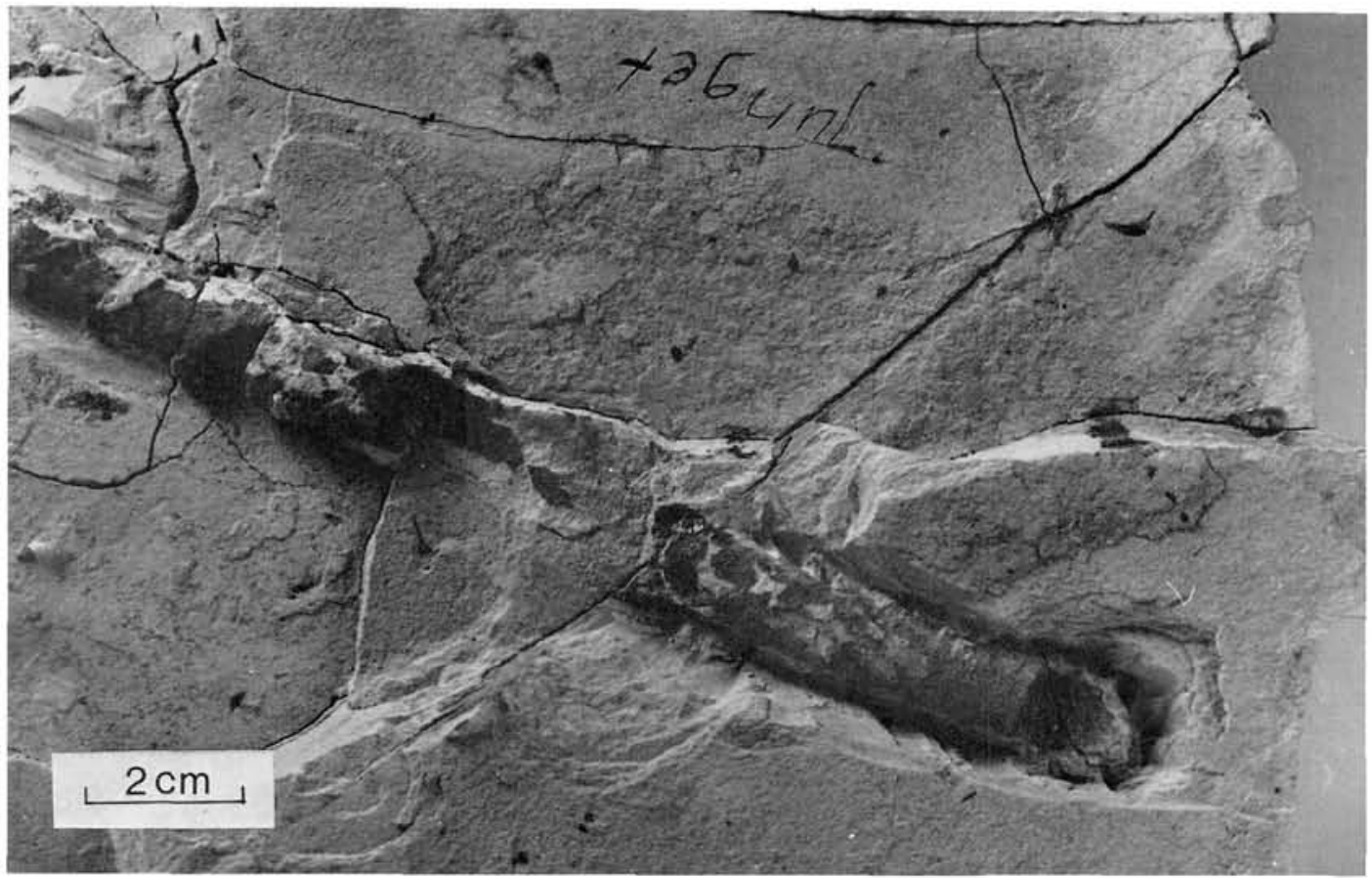

Fig. 8. Planolites. Subhorizontal ash-filled straight burrow beneath a thin layer of volcanic ash. Wieved from below.
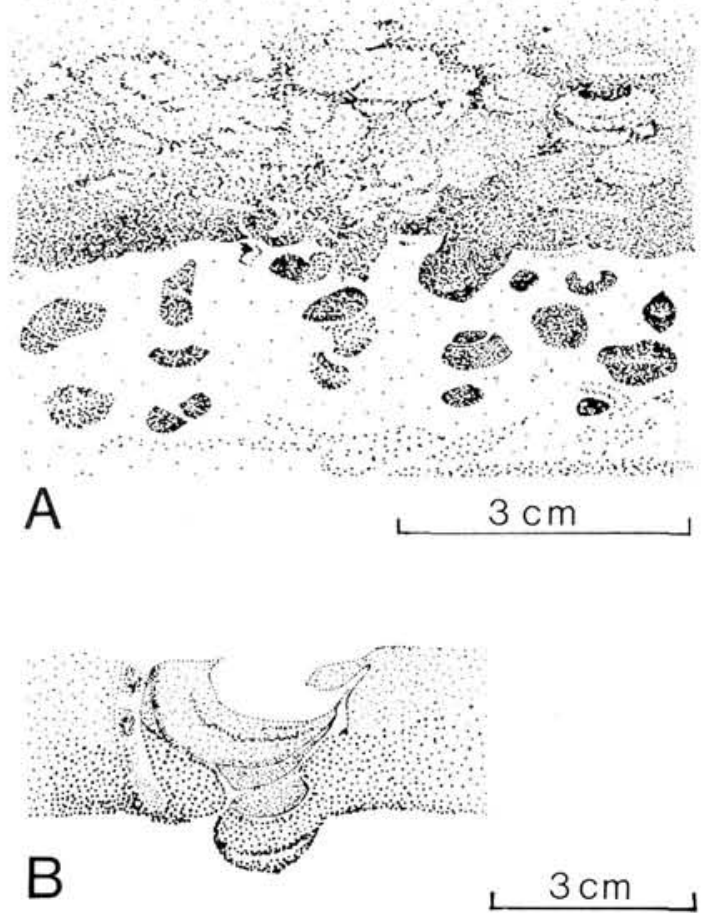

same diameter, c. $1 \mathrm{~cm}$ (fig. 8), and both occur beneath ash layers or extend down from them (fig. 9). As transitional forms exist resembling Phycodes (fig. 7F) it is suggested that Planolites and Teichichnus were created by animals of the same or of closely related species.

Chondrites, type C of Osgood (1970) consists of a central burrow with short side branches, all c. $0.5 \mathrm{~cm}$ in diameter (fig. 10), which again may be branching though never to the extent shown in the idealized Chondrites of Simpson (1957). The trace fossil always occur as hypichnial ridges on ash layers and is the only trace fossil that might be genetically related to the ash layers.

The ichnogenus Taenidium is characterized by cylindrical tubes with distinct meniscus-fill (Toots, 1967; Häntzschel, 1975). The tubes are often branching (Häntzschel, 1975), and Toots

Fig. 9. A: Numerous Teichichnus and Planolites whithin and below ash layer +36 , Silstrup. Some of the cross sections resemble Phycodes palmata.

B: Ash filled Teichichnus. 

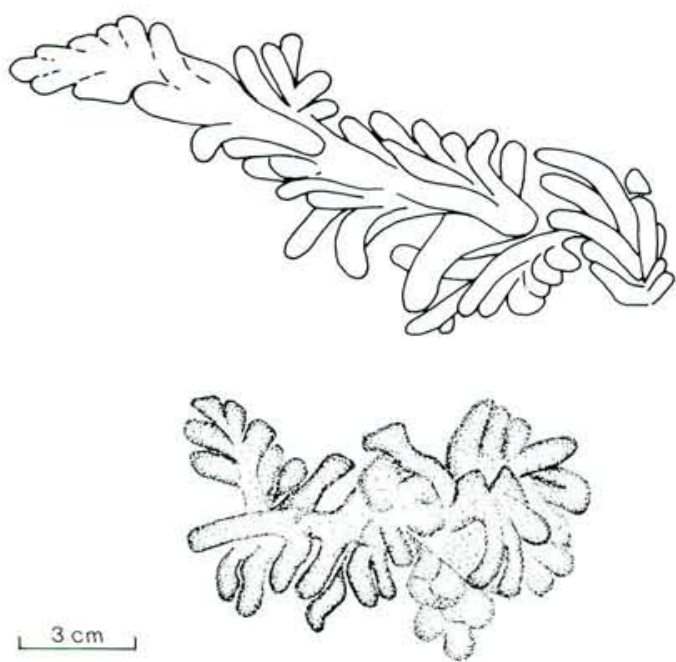

Fig. 10. Trace fossil reminiscent of Chondrites, type $\mathrm{C}$ of Osgood (1970). Both traces are preserved as hypichnial ridges on soles of ash layers incorporated in calcareous concretions. The lower was collected at Ertebølle, as was the sample fig. 333 in Andersen (1944), where the trace fossils are interpreted as algal remains.

(1967) reports diametres of 11-13 mm. Seilacher (1955, fig. 5) mentions Taenidium fischeri as "Stopfbau ähnlich Chondrites mit regelmässiger Quergliderung (Stopf-Portionen!)".

Taenidium ichnosp. (figs 11, 12) occurs as a system of branching tubes with meniscus backfill structures. The diameter of the tubes is c. $1 \mathrm{~mm}$. They are straight or can be divided into straight segments $3-7 \mathrm{~mm}$ long forming angles of $45^{\circ}-90^{\circ}$ with each other. A reconstruction of the burrow is attempted in fig. 11D. The trace fossil resembles Chondrites but deviates from this ichnogenus in branching dichotomously at varied angles while Chondrites has side-branches and branches at constant angles. Taenidium ichnosp. also shows meniscus backfill structures which are only rarely reported in descriptions of Chondrites, though mentioned in passing by Seilacher (1977, p. 332).

Taenidium ichnosp. has been observed as diatomite-filled burrows in the top of ash layers and in otherwise structureless diatomite immediately above, but they have not been observed beneath ash layers.

The trace fossil producing oganisms thus apparently occupied three different positions in relation to the ash layers: Teichichnus and Planolites were created by animals which lived in diatomite and burrowed through the thinner ash layers into the diatomite below. Chondrites, type $\mathrm{C}$ was produced by animals who exploited the boundary layer between diatomite and the soles of the ash layers. In contrast Taenidium ichnosp. was formed by organisms which lived in the diatomite and burrowed into the top of ash layers but not through these. The trace fossil producing animals thus seem to have explored different substrate niches. The ichnocoenosis is, however, uniform in composition throughout the non-laminated parts of the formation suggesting that the sediment changed little as a substrate for infaunal animals. The relatively high density and low diversity of the ichnocoenosis is taken to indicate low sedimentation rate in a high stress depositional environment.

The ash layers - The thickness of the numbered ash layers ranges from 1 to $20 \mathrm{~cm}$, but several thinner ash layers also occur (Bøggild, 1918). The ash layers are mostly black, and are composed of glass particles with an average grain size within the very fine sand and silt fractions.

All the ash layers show graded bedding, and no sedimentary structures showing significant transport and redeposition of the ash by currents on

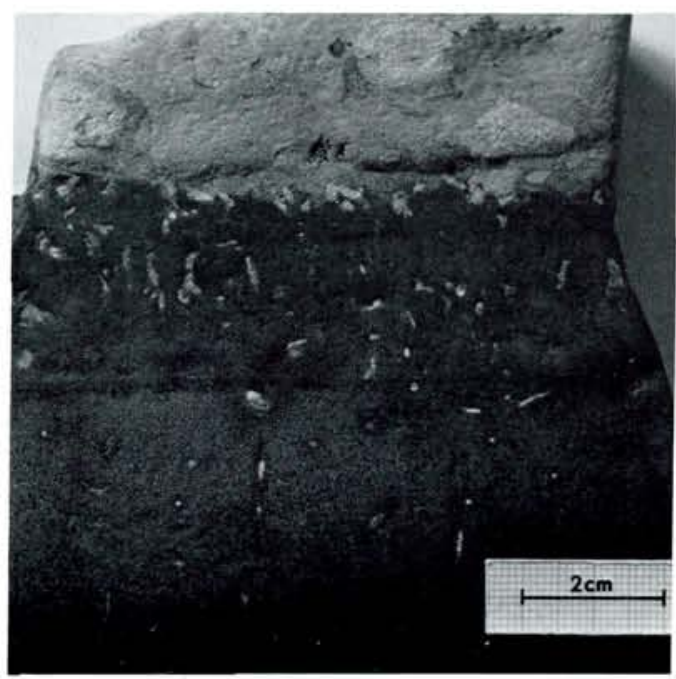

Fig. 11. Taenidium ichnosp.

Pale, diatomite-filled burrows, $1-2 \mathrm{~mm}$ in diameter in volcanic ash. The density of trace fossils is greatest at the top and diminishes downwards through the ash layer. Vague Planolites are seen in the diatomite. Probably ash layer +101 , loose calcareous concretion. 


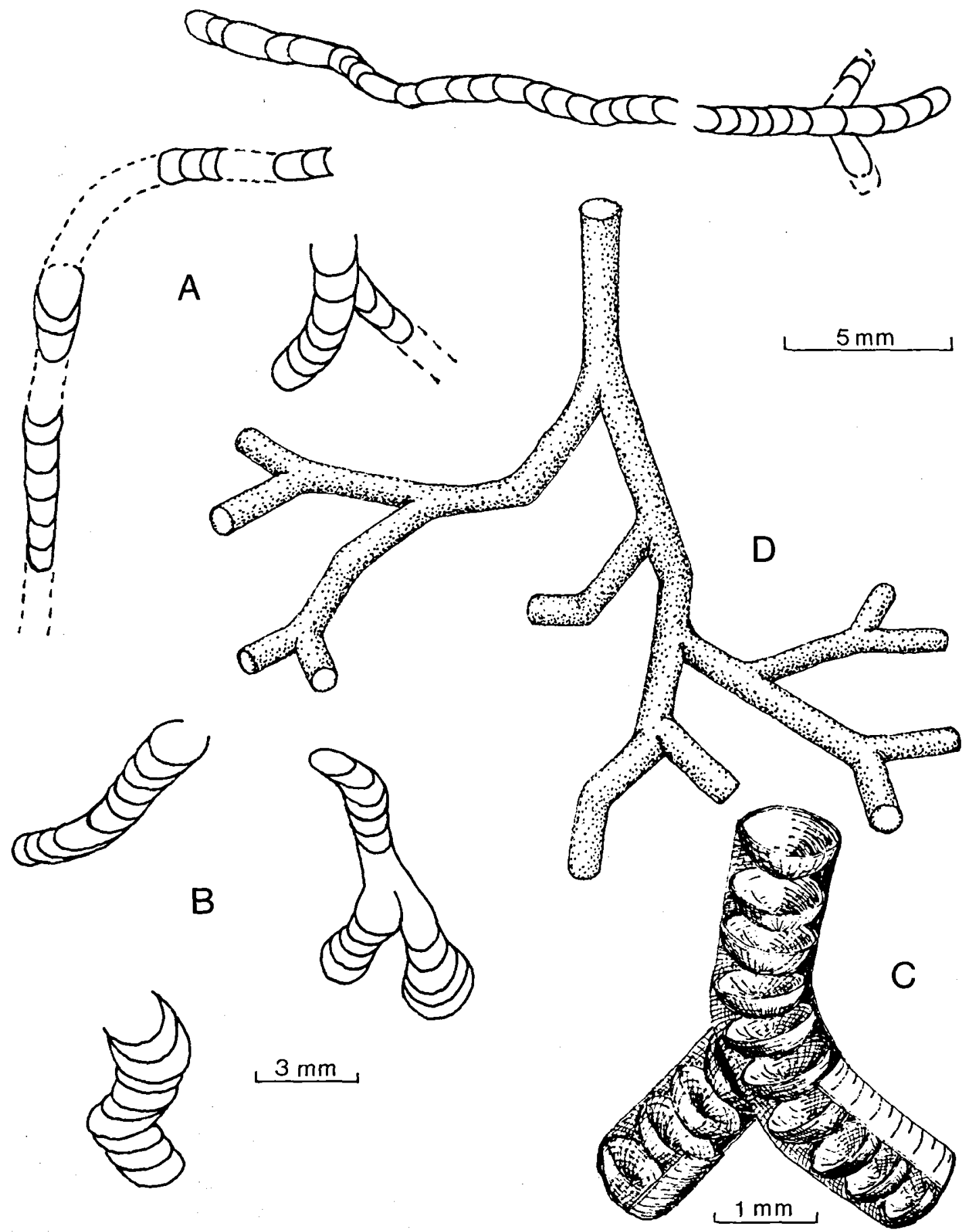

Fig. 12. Taenidium ichnosp.

A: details of horizontal sections through the burrow.

B: details of vertical sections through the burrow.

C: at any given time only a minor part of the burrow was open, because the animal stuffed material into disused parts of the burrow system.

D: reconstruction of the burrow. 
the sea-floor have been observed. Dish and pillar structures formed by escaping pore water have been described from som layers (Pedersen \& Surlyk, 1977).

The ash layers were formed from airborne ash particles that settled grain by grain through the water column; their depositional rate was high. Very little volcanic glass occurs dispersed in the diatomite showing that deposition of volcanic ash only took place immediately after a major eruption, and that re-working was negligible.

Andersen (1937) demonstrated that individual volcanic ash layers can be recognized throughout the Danish Basin. The volcanoes are thought to have been in the Skagerrak (Bøggild, 1918; Andersen, 1937; Åm, 1973). The petrology of the ash has recently been described by Pedersen, Engell \& Rønsbo (1975), Rønsbo, Pedersen \& Engell (1977) and Pedersen \& Jørgensen (1981). The morphology and grain size of the ash-shards indicate both subaerial and phreatic activity. The main part of the basaltic tephras are distinctly Surtseyan in type, which may indicate volcanism in a shallow sea (Pedersen \& Jørgensen, 1981).

The ash layers are of great stratigraphical importance as they originate from airborne ash, which was sedimented vertically through the water column within a very short time and without subsequent redeposition. Accordingly they can be considered isochronous horizons. The thickness of the individual ash layers varies regionally, but within the limited area of the diatomite basin the thickness of each layer is almost constant. The thickness of diatomite between two ash layers shows only minor variations. Therefore the ash layers are identifiable and a detailed tephra chronology with 179 ash layers numbered -39 to +140 has been established by Bøggild (1918) with supplementary data in Gry (1940).

Calcareous concretions - Calcareous concretions are found at certain levels in the diatomite (figs 3, $4)$. The close control provided by ash layers between +1 and +130 reveals that concretions are restricted to particular levels in the sequence throughout the basin. Within these levels, however, the size and number of the concretions may vary. Below ash layer +1 the concretions are probably confined to distinct levels too, but this is difficult to prove as the ash layers are fewer and more widely spaced. The concretions are usually ellipsoidal with a maximum size of $1 \times 0.5 \mathrm{~m}$, but continuous layers occur locally.

Andersen (1944) noted that some of the levels of calcareous concretions may be recognized in $\emptyset \mathrm{lst}, \mathrm{c} .100 \mathrm{~km}$ from the area of the Fur Formation, in a sequence of clay with abundant diatoms.

The concretions are predominantly found in laminated diatomite containing no or only a few thin ash layers (figs 3,4 ), with the concretions including ash layers $+101 / 102$ as a notable exception.

The diatomite outside the concretions is only slightly more compacted than within them, which might indicate a relatively late diagenetic age of the concretions. Andersen (1944) suggested an early diagenetic age as the diatom frustules are less crushed within than outside the calcareous concretions.

\section{Boundaries}

In all exposures the Fur Formation occurs as glacially dislocated and folded units (Gry, 1940). The formation has not been observed in an undisturbed position, although Gry (1979) suggested that this may be the case on Livø, where the formation is known from a well. The Fur Formation is more clayey in its uppermost and especially in its lowest parts, but the lithological contrast to the over- and underlying clay formations is sufficiently sharp for major dislocation surfaces to be located here. The contact between the Fur Formation and the overand underlying formations may thus only rarely be directly observed. The clayey diatomite of the Fur Formation is laterally replaced by dark grey non-calcareous clay, which has been studied in detail in the clay pits at Ølst and Hinge (Nielsen, 1974; Friis et al., 1981). The clay contains some usually poorly preserved diatoms (Bøggild, 1918; Benda 1965). Bøggild (1918) describes the boundary between the two lithologies as transitional taking place through a sequence of diatomaceous, pale-weathering clay reminiscent of the Fur Formation diatomite. Such transitional facies are referred to the Fur Formation in those cases where the sediment is still dominated by diatoms. 
Lower boundary

The Fur Formation is underlain by grey, slightly calcareous clay (Dinesen et al. 1977) and the boundary is exposed in Stolleklinten (fig. 2). The section is, however, incomplete as the lowest ash layer present is -34 , and the boundary between the two formations may thus be tectonical. The presence of a sedimentary hiatus cannot, however, be excluded. The lowest part of the Fur Formation which includes ash layers -34 to -39 , is only known from Fur Knudeklint (Bøggild, 1918; Gry, 1940) but exposures of this sequence are not presently accessible. Bøggild (1918) suggested a gradational transition between the diatomite and the underlying grey clay after inspection of samples collected at Klitgård by K. J. V. Steenstrup in 1882.

\section{Upper boundary}

The uppermost ash layer recognized in the Fur Formation is +140 which is only known from the exposure at the south cliff at Silstrup (fig. 3). The Fur Formation is here overlain by dark micaceous clay of Oligocene age (Ravn, 1907; Heilmann-Clausen, 1982). Several thin, glauconite-rich bands are seen at and above the boundary (also rapported by Bøggild, 1918 p. 50), which in the southern part of the cliff is gradational. Further north burrows up to $10 \mathrm{~cm}$ deep and filled with glauconite-rich brown clay extend downwards from the clay into the top of the Fur Formation.

In Fur Knudeklint the uppermost ash layer recognized is +130 (Heilmann-Clausen, 1982) and the diatomite is overlain by a siliceous bed, grey and greenish grey clay (the Knudshoved Member of the Røsnæs Clay) followed by redbrown Røsnæs Clay (Perch-Nielsen, 1976; Dinesen et al. 1977; Friis et al, 1981; Heilmann-Clausen, 1982). Heilmann-Clausen (1982) indicates a hiatus between the Fur Formation and the overlying Knudshoved Member of earliest Eocene age.

\section{Distribution}

The known occurrences of the Fur Formation are shown on fig. 15. The Fur Formation is limited to the east, north and west by structural highs, where Cretaceous and Danian chalk and limestone constitute the pre-Quaternary surface. The area to the south was a major depocentre and the sequence is penetrated by two salt domes.

\section{Geological age}

The age of the Fur Formation has been much debated through the last hundred years. As early as in 1899 Stolley correlated the Fur Formation with the Eocene London Clay on basis of the diatoms, the gastropod Cassidaria ("Fusinus" sp. of Bonde, 1974), and the plant Daphogene kanei (Heer). Danish geologists continued, however, to discuss the relationships of the formation to deposits containing calcareous invertebrates of Eocene or Oligocene age (Ravn, 1897, 1906, 1907; Bøggild, 1903; Ussing, 1904) until Grönwall (1908) established an Early Eocene age of the formation. Harder (1922) and Rosenkrantz (1924) both referred the Fur Formation to the Londonian Stage of the Upper Paleocene, while Gry (1935) stated that the ash-bearing formations, including the Fur Formation, lithologically were more similar to the Eocene than to the Paleocene deposits of Denmark. An Early Eocene age has lately been suggested by Thiede, Nielsen \& Perch-Nielsen (1980) on the basis of nannofossil investigations of strata containing the same ash layer sequence as the Fur Formation.

The lack of diagnostic calcareous microfossils in the Fur Formation as well as in contemporaneous clays has prolonged the discussion of the age of the Fur Formation. On the basis of silicoflagellates the Fur Formation has been referred to the Dictyocha deflandrei and $D$. naviculoidea Zones (Martini, 1974), while Perch-Nielsen (1976) placed it in the Naviculopsis constricta Zone of late Paleocene-early Eocene age (Bukry \& Foster, 1974; Busen \& Wisen, 1977).

The most recènt biostratigraphical studies are centered on the dinoflagellates (Hansen, 1979; Heilmann-Clausen, 1982) and they are summarized in fig. 13. From this scheme it is seen that the Fur Formation as well as the uppermost parts 


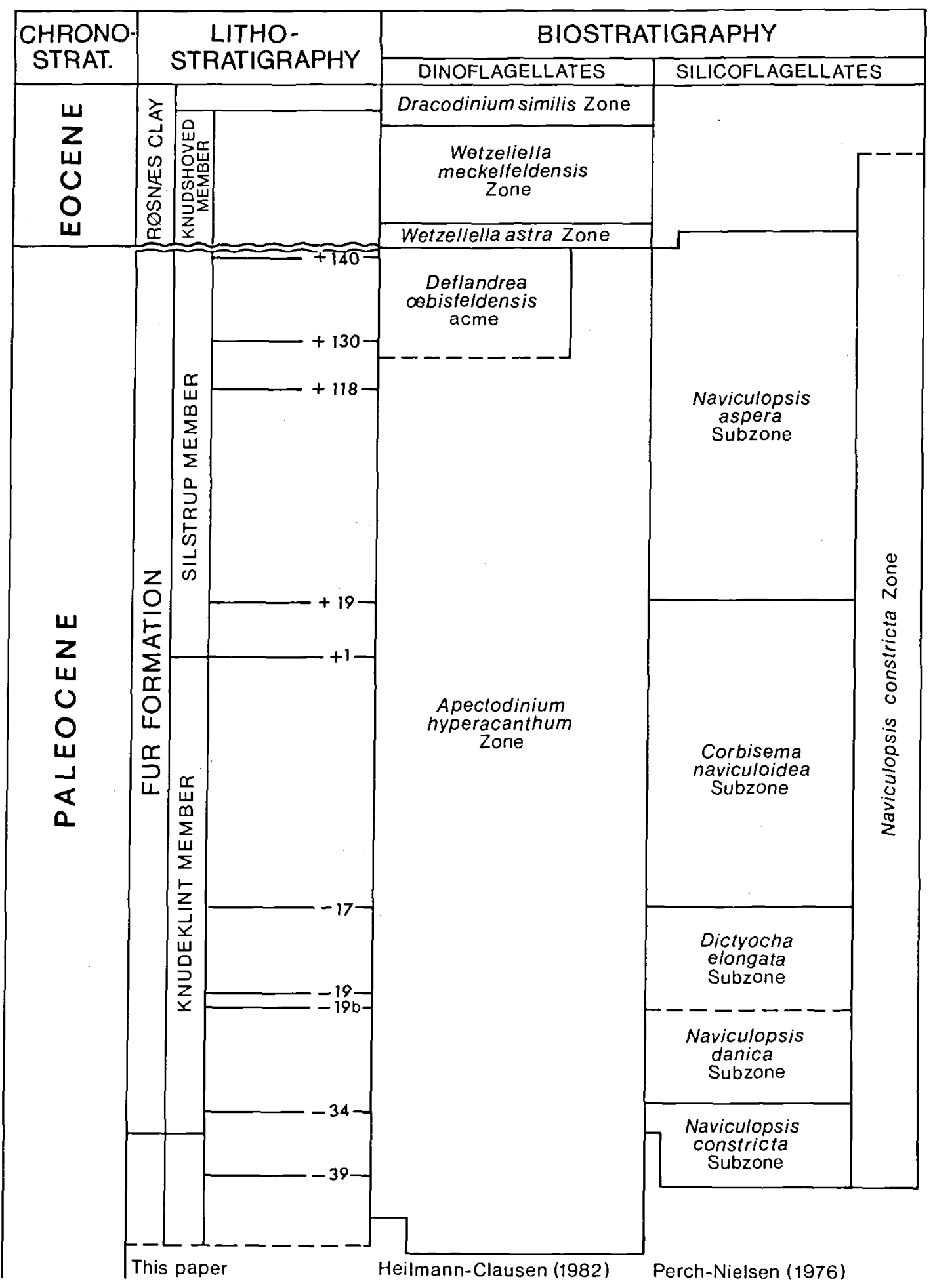

Fig. 13. Stratigraphical scheme. The Fur Formation overlies grey slightly calcareous clay. Both units contain a dinoflagellate assemblage belonging to the Apectodinium hyperacanthum Zone (Hansen 1979, Heilmann-Clausen 1982), and is thus of Late Paleocene age. In the uppermost part of the formation the Deflandrea oebisfeldensis acme, which Knox \& Harland (1979) describe as the uppermost part of the $\boldsymbol{A}$. hyperacanthum Zone, has been recognized. Heilmann-Clausen (1982) refers the sediments immediately above the Fur Formation in Fur Knudeklint to a new lithostratigraphical unit, the Knudshoved Member of the Røsnas Clay. The Knudshoved Member contains dinoflagellates of the Wetzeliella astra, the W. meckelfeldensis and the Dracocinium similis Zones (Heilmann-Clausen 1982) and is accordingly referred to the earliest Eocene. 
of the underlying grey, slightly calcareous clay (Dinesen et al., 1977) have dinoflagellate assemblages belonging to the Apectodinium hyperacanthum Zone (Hansen, 1979; HeilmannClausen, 1982). In the uppermost part of Fur Knudeklint the Deflandrea oebisfeldensis acme has been recognized (Heilmann-Clausen, 1982) which previously has been described from the uppermost part of the $A$. hyperacanthum Zone by Knox \& Harland (1979). In Fur Knudeklint the Wetzeliella astra Zone is identified in the siliceous bed at the base of the Knudshoved Member overlying the Fur Formation. The grey clay above this belongs to the $W$. meckelfeldensis Zone (Hansen, 1979; Heilmann-Clausen, 1982). A dinoflagellate zonation has been established in the Paris Basin across the Paleocene-Eocene boundary (Costa, Denison \& Downie, 1978). The Wetzeliella hyperacantha Zone is by Costa et al. (1978) referred to the Paleocene, while the base of the following $W$. astra Zone corresponds to the base of the Eocene. The W. astra Zone is overlain by the $W$. meckelfeldensis Zone of earliest Eocene age (Costa et al., 1978). Thus the dinoflagellates give evidence of a Late Paleocene age of the Fur Formation with the Paleocene-Eocene boundary located immediately above the formation.

\section{Knudeklint Member; (New Member) Name}

After Fur Knudeklint (figs. 2, 3)

Type section

Fur Knudeklint (figs 2, 3)

Reference sections

Stolleklint (figs 2, 4), Skarrehage (figs 2, 4)

Thickness

Approximately 34 m (fig. 3)
Lithology

The Knudeklint Member is characterized by laminated diatomite interbedded with relatively few widely spaced ash layers, numbered -39 to -1 . The diatomite is whitish, pinkish, locally light grey and usually soft. Ash-filled burrows below the ash layers are relatively scarce, in agreement with the predominance of laminated diatomite (cfr. fig. 6). Calcareous concretions occur in two levels: between ash layers -17 and -13 , and between -13 and +1 (fig. 4). Gry (1964) subdivided the Knudeklint Member, as here defined, into a lower unit ("skiferserie") of more clay-rich diatomite locally with silicified beds and containing the ash layers -39 to -20 , and an upper unit ("molerserie") of normal, clay-poor diatomite containing the ash layers -19 to -1 . This subdivision reflects the industrial utilization of the diatomite, which is restricted to the "molerserie" and the lowermost part of the overlying "askeserie"

\section{Boundaries}

The Knudeklint Member represents the Fur Formation from its base to the onset of dominantly structureless bioturbated diatomite approximately coinciding with the base of ash layer +1 . The member thus corresponds to the part of the formation which contains ash layers of the "negative series" of Bøggild (1918).

\section{Distribution}

Identical to that of the Fur Formation (fig. 15).

Age

Late Paleocene, but older than the Silstrup Member.

Silstrup Member; (New Member)

Name

After Silstrup Hoved (fig. 2) 
Type section

Type section in the south cliff at Silstrup (figs 2, 3)

\section{Reference sections}

Fur Knudeklint (figs 2, 3), Feggeklit (figs 2, 4)

Thickness

Approximately 26 m (figs 3, 4)

\section{Lithology}

The Silstrup Member is characterized by structureless diatomite interbedded with many ash layers. The diatomite is yellowish white and relatively hard. Ash filled burrows are frequent below or at the soles of ash layers, especially between +36 and +118 . Calcareous concretions occur in four horizons, between +16 and +19 , between +22 and +35 , around +101 to +102 and between ash layers +130 and +135 . Gry (1964) subdivided the Silstrup Member, as here defined, into a lower "askeserie" with numerous ash layers terminated by +119 , and an overlying "øverste serie" with few, thin ash layers $(+120$ to $+140)$. The latter is of some commercial interest.

\section{Boundaries}

The Silstrup Member represents the Fur Formation from the top of the Knudeklint Member (approximately at the base of ash layer +1 ) to the upper boundary of the formation. This boundary is in the south cliff at Silstrup located above ash layer +140 . The member corresponds to the part of the formation containing ash layers of "the positive series" of Bøggils (1918).

\section{Distribution}

Identical to that of the Fur Formation (fig. 15).
Age

Late Paleocene, but younger than the Knudeklint Member.

\section{Depositional environment}

Primary, mm-thick laminae are characteristic of the basic sedimentary facies in the diatomite (figs $4,5 a)$. The preservation of this lamination indicates the absence of an infauna and consequently anoxic or almost anoxic bottom water (Pedersen, 1978, 1981). The laminae are very thin and white, or thicker and pale brown. Bonde (1973, 1974) suggested that the laminae were regularly alternating and represented annual varves. This was shown not to be the case by Pedersen (1978, 1981) who demonstrated that the brownish laminae represent a background sedimentation of clay with diatoms. The white laminae are macroscopically uniform but include two different types. One is composed solely of diatoms while the other is composed of almost pure clay. The white laminae furthermore occur intercalated with the brown laminae in a highly irregular way. These observations clearly show that the diatomite cannot be interpreted as varved. Rather, a fairly constant clay deposition with a fluctuating admixture of diatoms was randomly punctuated by blooms of diatoms resulting in the formation of the first type of white laminae. The second type may reflect large episodic supplies of clay by rivers or possibly levels of increased diatom dissolution.

The diatomite consists of three sedimentary facies: structureless diatomite, weakly laminated diatomite, and laminated diatomite. These facies alternate through the Fur Formation (figs 4, 14) indicating changes between anoxic and slightly oxic bottom waters. It is characteristic that vertical facies changes occur simultaneously throughout the outcrop area and that lateral facies changes are insignificant. The ratio between structureless and laminated diatomite increases upwards indicating a gradual improvement in ventilation possibly corresponding to the filling of an initial depression (cf. Hallam \& Bradshaw 1979). The changes in oxygen content probably were small, varying from below $0.1 \mathrm{ml} \mathrm{O}_{2} / 1$ to above $0.3 \mathrm{ml} \mathrm{O}_{2} / 1$ (Rhoads \& Morse 1971). De- 


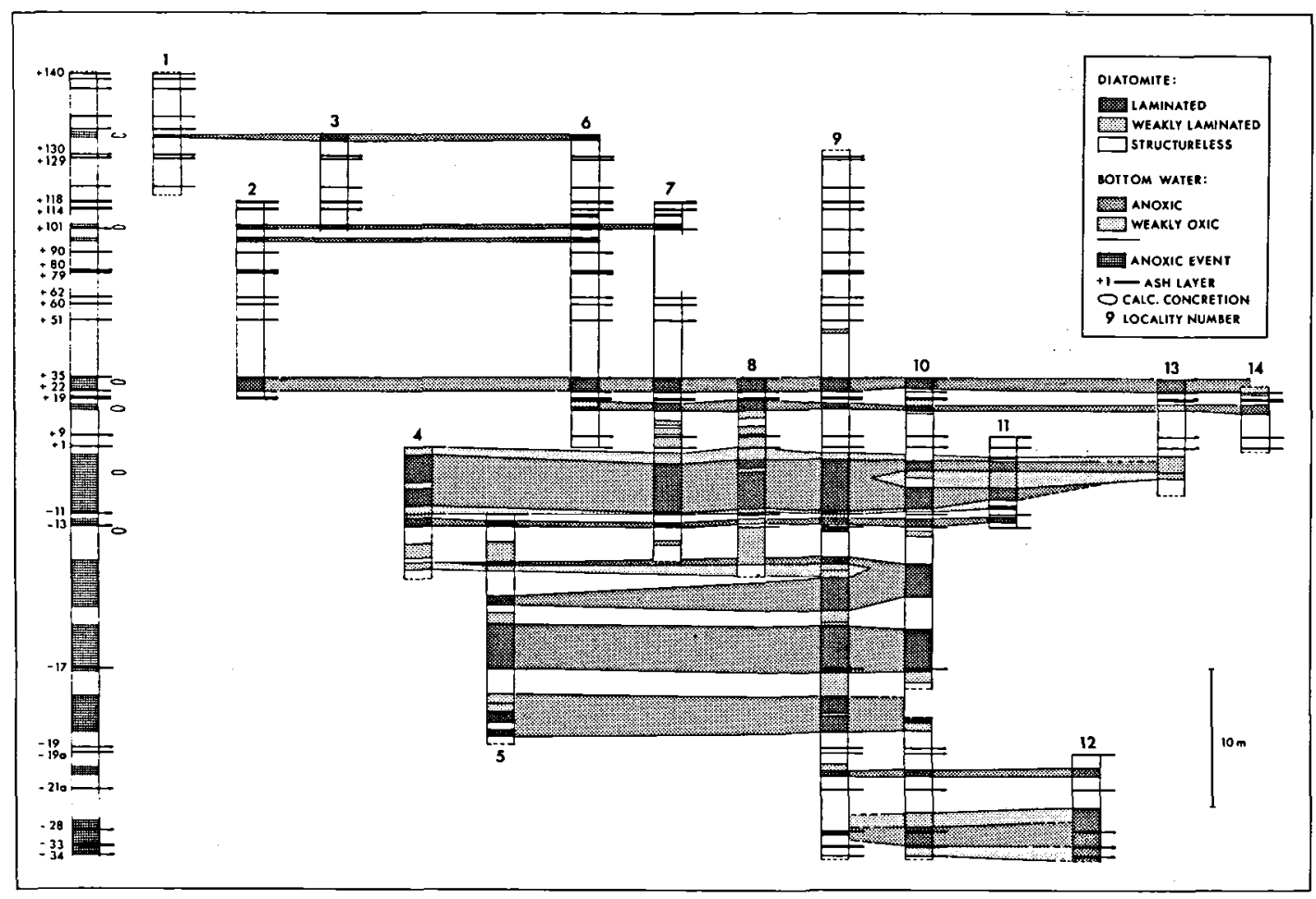

Fig. 14. Correlation of diatomite facies through the basin showing the existence of well-defined anoxic events. The sections have been standardized after section 9 so that the thickness between two ash layers is the same in all sections.

position thus took place in a water body with uniform and generally low oxygen content, which periodically became sufficiently high to allow the immigration of a sparse benthic fauna.

Very well-preserved macrofossils have been found in the Fur Formation. These are mainly fish and insects but also birds, turtles, and very rare ophiuroids and asteroids are reported. The occurrence of well-preserved vertebrate fossils in a relatively.slowly deposited sediment is another indication of the absecence of benthos including scavengers, from the sea floor.

Quantitative data on the number of fossils, the proportion between well-preserved and incomplete or damaged specimens, or data on the relationship between macrofossils and sedimentary facies are as yet lacking (cf. Kauffman 1978).

On the basis of the varve hypothesis Bonde $(1973,1974)$ calculated that the c. $60 \mathrm{~m}$ thick Fur Formation was deposited within c. 60.000 years. The varved nature of the diatomite was shown to be false by Pedersen $(1978,1981)$. The sedimentation rate of the diatomite is thus still unknown. Other estimates of the rate of deposition are indirect but suggest diatomite deposition in a period of the order of 1-3 million years. These estimates are based on the recognition of magnetic reversals in the ash layers (Sharma, 1969), on a succession of silicoflagellate subzones (Perch-Nielsen, 1976), and on recognition of four successive stages in the evolution a magmatic province whithin the ash-layer sequence (Pedersen, Engell \& Rønsbo, 1975).

The Fur Formation contains c. $65 \%$ (by weight) of marine diatoms, many of which appear to be unaffected by dissolution (Pedersen, 1978). This suggests a high production of diatoms and a fairly rapid deposition, perhaps as faecal pellets, because studies of recent diatomaceous deposits have shown, that a large proportion of the diatoms are dissolved before sedimentation (Calvert, 1966, 1968, 1974; Schrader, 1971, 1972). The production of diatoms requires light and a constant supply of nutrients, and the production is generally highest in areas of upwelling (Calvert, 1974). Accordingly Bonde (1973, 1974;-1979) 


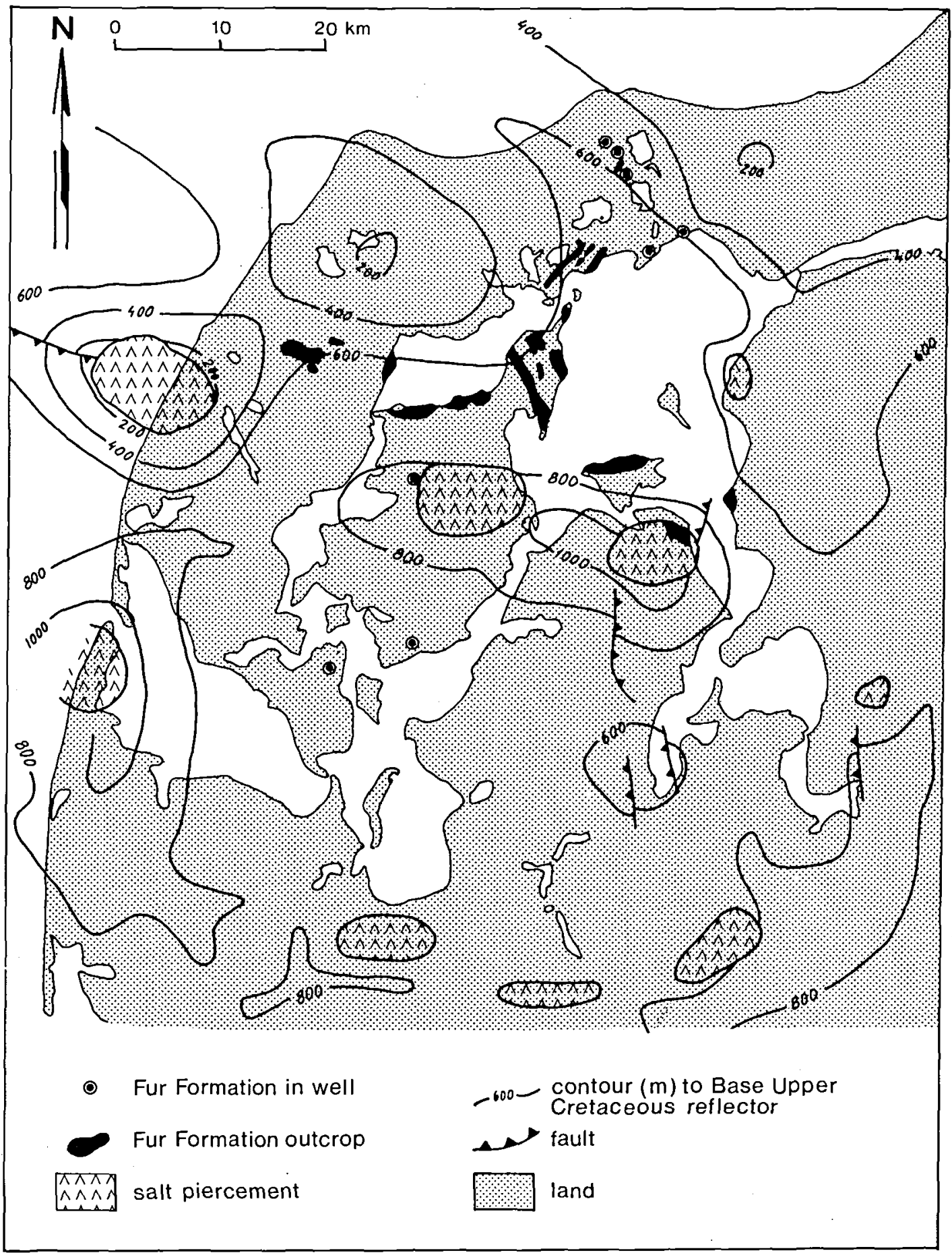

Fig. 15. Known occurrence of the Fur Formation (Petersen 1982) plotted on a structural map of the base Upper Cretaceous seismic reflector (Michelsen et al. 1981, fig. 37).

The $600 \mathrm{~m}$ contour corresponds roughly to areas where Cretaceous and Danian limestone constitutes the pre-Quaternary surface, while these deposits are covered by younger Tertiary sidements in the rest of the area. The distribution of the Fur Formation corresponds to the slope between the northern stable area and the southern subsiding area. Note that the Fur Formation was deposited within an area of rising salt dispirs. 
suggested that the Fur formation was deposited in an extensive zone of coastal upwelling. While this is still an open possibility, we feel that the available data suggest that the diatomite was formed in a much smaller area of local upwelling.

The Fur Formation is of restricted areal extent (fig. 15). It was deposited within an area surrounded by salt diapirs and characterized by structural highs to the north, west and east and structural lows to the south (fig. 15).

Bonde $(1979,1982)$ cites a personal communication from Inger Bang according to whom the $\mathrm{C}-1$ well in the Danish North Sea should have pentrated the Fur Formation. Re-examination of the few samples of cuttings shows that the lithology is not a diatomite but a pale grey silty claystone with diatoms, probably Coscinodiscus, interbedded with volcanic ash. Deposition of diatomite is thus most probably a local phenomenon.

South- and eastward the Fur Formation grades laterally into dark grey to blackish, locally laminated clay with poorly preserved diatoms. In the central North Sea laminated diatomaceous clay pass upward into the ash-sequence, and both of these lithological units belong to the $D$. oebisfeldensis acme of the $A$. hyperacanthum Zone (Knox \& Harland, 1979). They are thus contemporaneous with the upper parts of the Fur Formation and its lateral equivalents.

During the latest Paleocene large parts of the North Sea Basin thus seems to have been characterized by deposition of laminated clays under wholly or partly anoxic conditions (Bonde, 1979, 1982; Knox \& Harland, 1979). Bonde $(1974,1979)$ related this environment to an upwelling system within an enclosed sea. Deposition in a shallow restricted lake-like sea with stagnant bottom conditions was proposed by Knox \& Harland (1979).

It must be stressed, however, that though smectite-rich diatomaceous clay was deposited throughout the North Sea, the only true diatomite known from this area is the Fur Formation. While this formation is much thicker than the contemporaneous laterally equivalent sediments, the amount of clay is roughly the same. This indicates that the Fur Formation may be regarded as a local phenomenon, where the normal deposition of clay is strongly overprinted by an extraordinary supply of diatoms. It should, however, be mentioned that shales contemporaneous with the upper part of the Fur Formation from the northern Viking Graben are characterized by a high content of microcrystalline quartz supposedly of biogenic origin (Malm et al., 1983). This may suggest that high diatom productivity sufficient to form diatomite facies occurred relatively commonly during Late Paleocene times.

The gradual upward increase in the ratio of structureless to laminated diatomite (figs 4,14 ) is indicative of progressive ventilation accompanying the infilling of an initial topographical depression (cf. Hallam \& Bradshaw, 1979). It is therefore considered an attractive hypothesis that there is a direct relationship between the bottom topography and the circulation pattern, which governed the production of diatoms. The irregular bottom topography was probably caused by updoming over rising halokinetic structures and contemporaneous formation of rim synclines (fig. 15).

\section{Summary and conclusions}

The Fur Formation is erected to cover a local Late Paleocene diatomite occurrence in northern Jutland. The diatomite contains 179 numbered ash layers which represent isochronous horizons. The formation is subdivided into a lower Knudeklint Member characterized by laminated diatomite interbedded with relatively few ash layers, and an upper Silstrup Member characterized by structureless diatomite densely interbedded with ash layers. The Fur Formation was deposited in a sea characterized by water depths exceeding wave-base and practically unaffected by currents. The relatively high number of land-derived fossils such as insects, plants and birds, indicates relatively short distances to vegetation covered areas.

The lamination, which occur throughout the formation, illustrates that the diatomite was deposited relatively slowly as a mixture of clay and diatom frustules, interrupted by brief depositional events of either clay or diatoms. No temporal changes in this sedimentary pattern or in the rate of deposition can be detected.

The ichnocoenosis is of low diversity but relatively high density, a composition characteristic of high-stress environments. The infauna con- 
sisted of soft-bodied deposit feeding organisms. Calcareous shelled benthic animals were very rare, and the benthos was permanently low in numbers as indicated by the perfect state of preservation of fish and insects.

The alternation between laminated and bioturbated, structureless diatomite reflects recurring changes between periods with anoxic bottom water, with oxygen centents below $0.1 \mathrm{ml} \mathrm{O}_{2} / 1$, and periods with partial oxygenation of the bottom water, with oxygen contents between 0.5 and $1.0 \mathrm{ml} \mathrm{O} / 1$. The upper limit is inferred from the absence of calcareous fossils.

The isochronous ash layers demonstrate that the facies changes occurred simultaneously throughout the Fur Formation. The upwards increase in the ratio of structureless to laminated diatomite is thought to indicate increasing ventilation accompanying the infilling of an initial topographical depression. The irregular bottom topography was probably caused by updoming over rising halokinetic structures and the contemporaneous formation of rim synclines. Such local topographically induced variations in content of dissolved oxygen was probably overprinted by large-scale fluctuations in oxygenation in the main North Sea basin.

Acknowledgements. N. Bonde is thanked for constructive discussions. R. G. Bromley critically read the section on ichnology. G. K. P. thanks S. A. Schack Pedersen for encouragement and practical help in the preparation of parts of the manuscript. N. Turner, J. Lautrup, B. Sikker Hansen contributed with technical assistance. F. S. publishes with the permission of the Director of the Geological Survey of Greenland.

\section{Dansk Sammendrag}

Fur Formationen opstilles som betegnelse for en diatomit (moleret) af sen Paleocæn alder, som forekommer lokalt i Nordjylland. Diatomiten indeholder 179 nummererede lag af vulkansk aske og disse muliggor en korrelation imellem de dislocerede flager, hvori formationen er blottet. Formationen opdeles i et nedre Knudeklint Led bestående af lamineret diatomit med relativt få askelag, og et øvre Silstrup Led domineret af strukturløs diatomit med en stor tæthed af askelag.

Fur Formationen aflejredes i et hav på dybder, der var upåvirkede af bølge- og strømbevægelser. Det relativt store antal fossiler af terrestrisk oprindelse såsom insekter, planter og fugle viser dog, at afstanden til vegetationsdækkede landområder var forholdsvis kort.

Igennem hele formationen kan iagttages en lamination, der illustrerer, at diatomiten blev aflejret relativt langsomt som en blanding af ler og diatomeer. Tynde lamina, bestående udelukkende af diatomeer eller af ler, afspejler episodiske forggelser $i$ produktionen af diatomeer eller $i$ aflejringen af ler. Der har ikke kunnet konstateres systematiske variationer af dette aflejringsmønster igennem lagserien.

Sporfossilselskabet udviser en lav diversitet men en relativt høj densitet, og dermed en sammensætning, der er karakteristisk for høj stress miljøer. Infaunaen udgjordes af sedimentædende dyr uden hårde skeletdele, hvorimod kalkskallede benthiske organismer var meget fåtallige. Den perfekte bevaringstilstand af fiske- og insektfossiler viser, at bundfaunaen til stadighed var sparsom.

De sedimentære facies, hvis yderpunkter er den laminerede og den strukturløse, bioturberede diatomit, veksler op gennem lagsøjlen. Disse ændringer afspejler gentagne skift mellem perioder med meget iltfattigt bundvand, svarende til iltindhold under $0.1 \mathrm{ml} \mathrm{O} / 1$, og perioder med en delvis iltning af bundvandet, iltindhold mellem $0.5 \mathrm{og} 1.0 \mathrm{ml} \mathrm{O} / 1$. Den angivne ovre granse er udledt af, at kalkskallede fossiler er så fătallige igennem hele formationen.

De vulkanske askelag er isokrone og udgør dermed et fremragende grundlag for en kortlægning af den laterale og den vertikale udbredelse af de sedimentære facies. Det kan vises, at faciesskiftene var samtidige igennem hele Fur Formationen. Der er en generel stigning opad i formationen i forholdet mellem strukturløs og lamineret diatomit. Dette formodes at reflektere forbedret ventilation $i$ forbindelse med udfyldningen af en topografisk depression i aflejringsområdet. Den uregelmæssige bundtopografi var formodentlig forårsaget af bevagelser $i$ saltstrukturer $\mathrm{i}$ undergrunden. Lokale topografisk forårsagede variationer i mængden af opløst ilt fandt sandsynligvis sted på en baggrund af storskala variationer $i$ iltindhold $i$ hele Nordsø bassinet.

\section{References}

Andersen, S. A. 1937: De vulkanske Askelag i Vejgennemskæringen ved Ølst og deres Udbredelse i Danmark. Danm. geol. Unders. 2. rakke 59: 52 pp.

Andersen, S. A. 1944: Moleret og de vulkanske askelag: In Det danske Landskabs Historie, 1. Bind, Undergrunden: $391-415$.

Atterberg, A. 1903: Studier i Jordanalysen 1-6. LandbruksAkad. Handl. och Tidskr. H. 3: 185-254.

Benda, L. 1965 Diatomeen aus dem Eozän Norddeutschlands. Paläontol. Zeitschr. 39: 165-187.

Benda, L. 1972: The Diatoms of the Moler Formation of Denmark (Lower Eocene). A Preliminary Report. In Simonsen $(E d$.$) : First symposium on recent and fossils marine$ diatoms. Beih. Nova Hedwigia 39: 251-266.

Bonde, N. 1966: The fishes of the mo-clay formation (Lower Eocene). Medd. Dansk Geol. Foren. 16: 198-201.

Bonde, N. 1973: Fiskefossiler, diatomiter og vulkanske askelag. Dansk geol. Foren. Arsskrift for 1972: 136-143.

Bonde, N. 1974: Palaeoenvironment as indicated by the "mo-clay formation" (Lowermost Eocene of Denmark). Tertiary Times 2: 29-36.

Bonde, N. 1979: Palaeoenvironment in the "North Sea" as indicated by the fish bearing Mo clay deposit (Paleocene/Eocene), Denmark. Meded. Werkgrp. Tert. Kwart. Geol. 16: 3-16.

Bonde, N. 1982: Teleostei (bony fish) from the Norwegian North Sea drillings. Norsk Geol. Tidsskr., 62: 59-65.

Buchardt, B. 1981: Tertiary deposits of the Norwegian-Greenland sea region (Svalbard, Northeast and East Greenland, Iceland, The Faeroe Islands and the Norwegian-Greenland Sea) and their correlation to Northwest Europe. Mem. Can. Soc. Petrol. Geol. 7: 611-645. 
Bukry D. \& Foster, J. H. 1974: Silicoflagellate zonation of Upper Cretaceous to Lower Miocene deep sea sediments. Jour. Res. U. S. Geol. Surv. 2: 303-310.

Busen, K. E. \& Wise, JR., S. W. 1977: Silicoflagellate stratigraphy, Deep Sea Drilling Project, Leg 36. In: Barker, P., Dalziel, I. W. D. et al.: Initial Reports of the Deep Sea Drilling Project 36: 697-718.

Bøggild, O. B. 1903: Vulkansk Aske i Moleret. Medd. Dansk Geol. Foren. 2: 1-12.

Bøggild, O. B. 1918: Den vulkanske Aske i Moleret, Danm. geol. Unders. 2 rk., 33: 84 pp.

Calvert, S. E. 1966: Accumulation of diatomaceous silica in the sediments of the Gulf of California. Geol. Soc. Am. Bull. 77: 569-596.

Calvert, S. E. 1968: Silica balance in the ocean and diagenesis. Nature 219: 919-920.

Calvert, S. E. 1974: Deposition and diagenesis of silica in marine Sediments. Spec. Publs. Int. Ass. Sediment. 1: 273-299.

Costa, L., Denison, C. \& Downie, C. 1978: The Paleocene/Eocene boundary in the Anglo-Paris Basin. $J$. geol. Soc. London, 135: 261-264.

Dinesen, A., Michelsen, O. \& Lieberkind, K. 1977: A survey of the Paleocene and Eocene deposits of Jylland and Fyn. Danm. geol. Unders., Ser. B, 1: 15 pp.

Forchhammer, G. 1835: Danmarks geognostiske Forhold, forsaavidt som de ere afhongige af Dannelser, der ere sluttede, fremstillede $i$ et Indbydelsesskrift til Reformationsfesten den 14de Novbr. 1835. Kjöbenhavn 112 pp.

Friis, H., Nielsen, O. B. \& Heilmann-Clausen, C. 1981: International Geological Correlation Programme Project 124, The NW European Tertiary Basin. Guide to excursion, 14th May, 1981. University of Aarhus: $71 \mathrm{pp}$.

Grönwall, K. A. 1908: En boring på Samsø og nogle deraf følgende Slutninger om Danmarks ældre Tertiær. Meddr Dansk geol. Foren. 3: 133-148.

Gry, H. 1935: Petrology of the Paleocene Sedimentary Rocks of Denmark. Danm. geol. Unders. 2 rk., 61: 172 pp.

Gry, H. 1940: De istektoniske Forhold i Molerområdet. Med bemærkninger om vore dislocerede Klinters dannelse og om den negative Askeserie. Medd dansk Geol. Foren. 9: 586-627.

Gry, H. 1964: Furs Geologi. Dansk natur-dansk skole. Arsskrift 1964: 45-55.

Gry, H. 1979: Beskrivelse til Geologisk Kort over Danmark, Kortbladet Løgstør. Danm. geol. Unders. Ser. 1, 26: 58 pp.

Hallam, A. \& Bradshaw, M. J. 1979: Bituminous shales and oolitic ironstones as indicators of transgressions and regressions. J. geol. Soc. Lond. 136, 157-164.

Hansen, J. M. 1979: Age of the Mo-clay Formation. Bull. geol. Soc. Denmark 27: 89-91.

Häntzschel, W. 1975: Trace fossils and problematica. In Moore, R. C. (ed.): Treatise on Invertebrate Paleontology, Vol. W. Geol. Soc. America and Univ. of Kansas Press: $122 \mathrm{pp}$.

Harder, H. 1922: Om Grænsen mellem Saltholmskalk og Lellinge Grønsand og nogle bemærkninger om inddelingen af Danmarks ældre Tertiær. Danm. geol. Unders. 2 rk., 38: $108 \mathrm{pp}$.

Hartz, N. 1909: Bidrag til Danmarks tertiære og diluviale Flora. Danm. geol. Unders. 2 rakk 20: 292 pp.

Heiberg, P. A. C. 1863: Conspectus criticus diatomacearum danicarum. Kritisk Oversigt over de danske Diatomeer. Kjöbenhavn 135 pp. and 6 plates Heie, O. E. 1970: Lower Eocene aphids (Insecta) from Denmark. Bull. geol. Soc. Denmark 20: 162-168.

Heilmann-Clausen, C. 1982: The Paleocene-Eocene boundary in Denmark. Newslett. Stratigr. 11: 55-63.

Henriksen, K. L. 1922: Eocene insects from Denmark. Danm. geol. Unders. 2 række 37: $36 \mathrm{pp}$.
Hoch, E. 1975: Amniote remnants from the eastern part of the Lower Eocene North Sea Basin. Colloque International C. N. R. S. No. 218 (Paris 1973): 543-562.

Kauffman, E. G. 1978: Benthic environments and paleoecology of the Posidonienschiefer (Toarcian). N. Jb. Geol. Paläont. Abh. 157: 18-36.

Knox, R. W. O’B. \& Harland, R. 1979: Stratigraphical relationships of the early Paleogene ash series of NW Europe. J. geol. Soc. London 136: 463-470.

Koch, E. 1960: Mødereferat fra palæontologisk klub, 9. november 1959. Meddr. dansk Geol. Foren. 14: 283.

Larsson, S. G. 1975: Palaeobiology and mode of burial of the insects of the Lower Eocene Mo-clay of Denmark. Bull. geol. Soc. Denmark 24: 193-209.

Malm, O. A., Christensen, O. B., Furnes, H., Lovlie, R., Rueslåtten, H., \& Østby, K. L. 1983: The Lower Tertiary tuff-marker (Balder Fm.) in the Viking Graben: composition, source, deposition and age. "North European margin symposium. (NEMS '83)" Trondheim, 9-11 May 1983. Norwegian Petroleum Society, 1 p.

Martini, E. 1974: Silicoflagellate zones in the Eocene and early Oligocene. Senckenbergiana Leth. 54: 527-532.

Martini, E. 1977: Neue Daten zum Paläozän und Unter-Eozän im südlichen Nordseebecken. Newslett. Stratigr. 6: 97-105.

Nielsen, E. 1959: Eocene turtles from Denmark. Medd. dansk Geol. Foren. 14: 96-114.

Nielsen, E. 1960: A new Eocene teleost from Denmark. Medd. dansk Geol. Foren. 14: 247-252.

Nielsen, E. 1963: On the post-cranial skeleton of Eosphargis breineri Nielsen. Medd. dansk Geol. Foren. 15: 281-328.

Nielsen, O. B. 1974: Sedimentation and diagenesis of Lower Eocene sediments at Ølst, Denmark. Sediment. Geol. 12: 25-44.

Osgood, JR., R. G. 1970: Trace fossils of the Cincinnati area. Palaeontographica Americana 6 41: 281-444.

Pedersen, A. K., Engell, J. \& Rønsbo, J. G. 1975: Early Tertiary volcanism in the Skaggerrak: New chemical evidence from ash-layers in the mo-clay of northern Denmark. Lithos 8: 255-268.

Pedersen, A. K. \& Jørgensen, K. O. 1981: A textural study of basaltic tephras from Lower Tertiary diatomites in northern Denmark. In S. Self \& R. S. J. Sparks (eds.): Tephra Studies. D. Reidel Publishing Company: 213-218.

Pedersen, G. K. 1978: Molerets Sedimentologi. Unpublished thesis. University of Copenhagen: $156 \mathrm{pp}$.

Pedersen, G. K. 1981: Anoxic events during sedimentation of a Paleogene diatomite in Denmark. Sedimentology 28: 487-504.

Pedersen, G. K. \& Surlyk, F. 1977: Dish structures in Eocene volcanic ash layers, Denmark. Sedimentology 24: 581-590.

Perch-Nielsen, K. 1976: New silicoflagellates and a silicoflagellate zonation in north European Paleocene and Eocene diatomites. Bull, geol. Soc. Denmark 25: 27-40.

Pontoppidan, 1763: Den danske Atlas; Konge-riget Dannemark, med dets naturlige Egenskaber, Indbyggere, Vaxter, Dyr og andre Affødninger, dets gamle Tildragelser og nuvarende Omstandigheder $i$ alle Provintzer, Stader, Kirker, Slotte og Herre-Gaarde. Forestillet ved en udførlig Lands-Beskrivelse, saa og oplyst med dertil forfardigede Landkort. Vol. 1, 435, 453; vol. 4, (1768), 771 pp.

Printz, W. 1885: A propos des coupes de diatomees du "Cementstein" du Jutland. Description mineralogique de cette roche. Bull. Soc. Belge de Microsc. 11: 147-194.

Printz, W. \& Ermengem, E. van 1883: Recherches sur la structure de quelques diatomees continues dans le "Cementstein" du Jutland. Ann. Soc. Belge de Microsc. 8: 1-74. 
Rasmussen, H. W. 1972: Lower Tertiary Crinoidea, Asteroidea and Ophiuroidea from Northern Europe and Greenland. Biol. Skr. Dan. Vid. Selsk. 19 7: 83 pp.

Ravn, J. P. J. 1897: Nogle bemærkninger om dansk Tertiæraflejringers Alder. Medd. Dansk Geol. Foren. 1: 1-16.

Ravn, J. P. J. 1906: Nogle bemærkninger om de oligocæne og miocæne Aflejringer i Jylland. Medd. Dansk Geol. Foren. 2: 1-6.

Ravn, J. P. J. 1907: Molluskfaunaen i Jyllands Tertiæraflejringer. D. Kgl. Danske Vidensk. Selsk. 7. Rk., Naturvidsk. og math. Afd. III 2.

Rhoads, D. C. \& Morse, J. V. 1971: Evolutionary and ecologic significance of oxygen-deficient marine basins. Lethaia, 4 : 413-428.

Rosenkrantz, A. 1924: De københavnske Grønsandslag og deres Placering $\mathrm{i}$ den danske Lagrakke. Medd. dansk Geol. Foren. 6: 1-39.

Rønsbo, J. G., Pedersen, A. K. \& Engell, J. 1977: Titan-aegirine from early Tertiary ashlayers in northern Denmark. Lithos, 10: 193-204.

Rørdam, K. 1909: Geologi og Jordbundslare II Bind, Danmarks Geologi. Gyldendalske Boghandel Nordisk Forlag: 225 pp.

Schrader, H.-J. 1971: Selektive Auflösung planktischer Diatomeen im Seegebiet zwischen 15-43 nordlicher Breite und 8-30 westlicher Lange. In Farinacci (ed.) Proc. 2nd Planctonic Conf. Roma 1970. 2: 1139-1147.

Schrader, H.- J. 1972: Anlösung und Konservation von Diatomeenschalen beim Absinken am Beispiels des Landorts-Tiefs in der Ostsee. Simonsen (ed.): First Symposium on recent and fossil marine diatoms. Beih. Nowa Hedwigia. 39: 191-216.

Seilacher, A. 1955: Spuren und Lebensweise der Trilobiten, Spuren und Facies im Unterkabrium. In Schindewolf, U. H. \& Seilacher, A. (eds.): Beitrage zur Kenntnis des Kam- briums in der Salt Range (Pakistan). Akad. Wiss. \& Lit. Mainz. Math.-Naturwiss. Kl., Abhandl., Jahreg. 1955, 10: 86-143.

Seilacher, A. 1977: Pattern analysis of Paleodictyon and related trace fossils. In Crimes, T. P. \& Harper, J. C. (eds.): Trace fossils 2. Geological Journal Special Issue No. 9: 289-334.

Simpson, S. 1957: On the trace-fossil Chondrites. Geol. Soc. London, Quart. Jour. 112: 475-499.

Sharma, P. V. 1969: Early Tertiary field reversals recorded in volcanic ash layers of Northern Denmark. Bull. geol. Soc. Denmark 19: 218-233.

Stolley, E. 1899: Über Diluvialgeschiebe des London Thons in Schleswig-Holstein und das Alter der Molerformation Jütlands sowie das baltische Eozän Überhaupt. Arch. $f$. Antropol. Geol. Schleswig-Holstein 3: 105-146.

Surlyk, F. 1980: Geology of the European countries, Denmark. Published in cooperation with the Comite National Français de Geologie (C. N. F. G.) on the occasion of the 26th International Geological Congress. Dunod: $64 \mathrm{pp}$.

Thiede, J., Nielsen, O. B. and Perch-Nielsen, K. 1980: Lithofacies, mineralogy and biostratigraphy of Eocene sediments in northern Denmark (Deep test Viborg 1). $N$. Jb. Geol. Paläont. Abh. 160: 149-172.

Toots, H. 1957: Invertebrate burrows in the non-marine Miocene of Wyoming. Wyoming Univ., Contrib. Geology 6: 93-96.

Ussing, N. V. 1904: Danmarks Geologi i almenfatteligt Omrids. Danm. geol. Unders. 3 rk., 2: 358 pp.

Willman, R. 1977: Mecopteren aus dem untereozänen Moler des Limfjordes (Dänemark). N. Jb. Geol. Paläont. Mh. 1977 12: 735-744.

Am, K. 1973: Geophysical indications of Permian and Tertiary igneous activity in the Skagerrak. Norges geol. Unders. 287: 1-25. 